\title{
Nurse-like Cells from Bone Marrow and Synovium of Patients with Rheumatoid Arthritis Promote Survival and Enhance Function of Human B Cells
}

\author{
Yasunori Shimaoka, ${ }^{\star}$ Jeanne F. Attrep, ${ }^{\ddagger}$ Toshio Hirano,§ Katsuhiko Ishihara, ${ }^{\S}$ Ryuji Suzuki,, Tomoko Toyosaki, \\ Takahiro Ochi, ${ }^{\star}$ and Peter E. Lipsky ${ }^{\ddagger}$ \\ ${ }^{*}$ Department of Orthopedic Surgery, Osaka University Medical School, 2-2, Yamada-oka, Suita, Osaka 565, Japan; ${ }^{\ddagger}$ Harold C. Simmons \\ Arthritis Research Center, Department of Internal Medicine, University of Texas Southwestern Medical Center at Dallas, Dallas, Texas \\ 75235; ${ }^{\S}$ Division of Molecular Oncology, Department of Oncology, Biomedical Research Center, Osaka University Medical School, 2-2, \\ Yamada-oka, Suita, Osaka 565, Japan; "Department of Immunology, Shionogi Research Laboratories, 5-12-4, Sagisu, Fukushima-ku, \\ Osaka 553, Japan
}

\begin{abstract}
Thymic nurse cells are known to interact with $\mathrm{T}$ cells and play a role in their functional maturation. However, the role of nurse cells in B cell maturation and differentiation is less well established, especially at extralymphoid sites. To address this issue, nurse-like cell clones from bone marrow and synovial tissue of patients with RA (RA-NLC) were established and characterized. RA-NLC constitutively expressed CD29, CD49c, CD54 (ICAM-1), CD106 (VCAM-1), CD157 (BST-1), and class I MHC molecules, and secreted IL-6, IL-7, IL-8, granulocyte-macrophage colony-stimulating factor (GM-CSF) and granulocyte colony-stimulating factor (G-CSF). Bone marrow-derived and synovial RANLC differed in that the former secreted IL-7 and expressed a greater density of CD157 constitutively and after stimulation with IFN $\gamma$, whereas the latter secreted G-CSF and more IL-6. Stimulation of both bone marrow and synovial RA-NLC induced expression of CD40 and class II MHC, but not CD154 (CD40L) or CD35. RA-NLC rescued peripheral $B$ cells from spontaneous apoptosis and promoted survival of B cells for $>4 \mathrm{wk}$. B cell survival was blocked by antibodies to CD106 or CD157. RA-NLC also increased Ig production from B cells. After long-term culture (4-6 wk) with RA-NLC, but not alone or with fibroblasts, outgrowth of B cells was observed. All B cell lines derived from these cultures had been transformed by EBV, although the RANLC themselves were not infected with EBV. Precursor frequency analysis indicated that $\sim 1$ in 12,500 peripheral $\mathrm{B}$ cells could give rise to these EBV-transformed $B$ cell lines upon coculture with RA-NLC. These results indicate that RA-NLC from bone marrow and synovium have the capacity to rescue $B$ cells from spontaneous apoptosis, facilitate Ig production, and promote the outgrowth of EBV-transformed B lymphoblastoid cells. These findings suggest that RA-NLC may play a role in the local and systemic hyperre-
\end{abstract}

Address correspondence to Peter E. Lipsky, M.D., Department of Internal Medicine, University of Texas Southwestern Medical Center at Dallas, 5323 Harry Hines Blvd., Dallas, TX 75235-8884.

Received for publication 19 February 1998 and accepted in revised form 28 May 1998.

J. Clin. Invest.

(C) The American Society for Clinical Investigation, Inc. 0021-9738/98/08/0595/13 \$2.00

Volume 102, Number 3, August 1998, 606-618

http://www.jci.org activity of B cells characteristic of rheumatoid arthritis. ( $J$. Clin. Invest. 1998. 102:606-618.) Key words: RA • B cells • apoptosis $\bullet$ stromal cells

\section{Introduction}

Nurse cells were first recognized in cell suspensions from dissociated thymus $(1,2)$. Thymic nurse cells form unique complexes with bone marrow-derived $\mathrm{T}$ cell precursors, and play an important role in thymocyte maturation and differentiation, eventually leading to the generation of positively $(3,4)$ or negatively (5) selected $\mathrm{T}$ cells that subsequently migrate to the $\mathrm{T}$ cell-dependent areas of secondary lymphoid organs. After initial adhesion to thymic nurse cells, thymocytes crawl beneath them in vitro $(6,7)$. This phenomenon, known as pseudoemperipolesis, is peculiar to nurse cells (8), and has been used to identify nurse-like cells (NLC) ${ }^{1}$ at various tissue sites. Previous studies have characterized NLC clones from human dermal tissue (9), and nurse-like stromal cell lines have been established from bone marrow of RA patients (10; Takeuchi, E., T. Tomita, T. Toyosaki-Maeda, H. Hashimoto, M. Kaneko, H. Takano, K. Sugamoto, R. Suzuki, and T. Ochi, manuscript submitted for publication). Moreover, NLC have been established from the synovium of RA patients (11; Tomita, T., E. Takeuchi, T. Toyosaki-Maeda, H. Oku, M. Kaneko, H. Takano, K. Sugamoto, K. Ohzono, R. Suzuki, and T. Ochi, manuscript submitted for publication). A common feature of all NLC was their capacity to support pseudoemperipolesis, similarly to thymic nurse cells. Thus, nurse cells may play an important role in extralymphoid immune responsiveness, as well as promoting maturation of $\mathrm{T}$ cells in the thymus.

In addition to their association with T cells, nurse cells have also been noted to interact physically with B cell lymphoma lines (9). This finding suggests that NLC may also promote B cell function, but the role of NLC in B cell maturation and differentiation has not been delineated. Furthermore, the functional potential of extrathymic nurse cells is not known.

RA is characterized by chronic inflammation with infiltration of a variety of inflammatory cells, including those of myeloid origin as well as $\mathrm{T}$ and $\mathrm{B}$ lymphocytes into the affected synovium. One feature of rheumatoid inflammation is local B cell activation, resulting in the production of large amounts of

1. Abbreviations used in this paper: BST-1, bone marrow stromal antigen-1; DT1, human dermal fibroblast cell line; FDC, follicular dendritic cells; G-CSF, granulocyte colony-stimulating factor; GM-CSF, granulocyte-macrophage colony-stimulating factor; MFI, mean fluorescence intensity; NLC, nurse-like cells; PE, phycoerythrin; RA-NLC, rheumatoid arthritis NLC; VCAM, vascular cell adhesion molecule. 
Ig and autoantibodies. The features of the synovium that promote local B cell differentiation are not completely delineated, although previous studies have suggested that extralymphoid $B$ cell activation in the rheumatoid synovium may be promoted by fibroblast-like synoviocytes. Thus, B lymphocytes, some of which expressed proliferating cell nuclear antigen, were noted to be in intimate contact with synoviocytes in the subintimal layer of the rheumatoid synovium (12), suggesting a role for this interaction in facilitating $\mathrm{B}$ cell responses locally. In addition, synoviocytes have been noted to support the terminal differentiation of activated B cells into immunoglobulinsecreting plasma cells (13). These results suggest a role for synoviocytes in facilitating local B cell responses in RA synovium. Whether the capacity to facilitate B cell activation is a general property of synoviocytes or, alternatively, reflects the activity of a small number of contaminating NLC is currently unknown.

These studies were undertaken to examine the possibility that NLC promote B cell as well as T cell activation and differentiation. To address these issues, NLC clones from bone marrow and synovial tissue of patients with RA (RA-NLC) were established and their capacity to promote $\mathrm{B}$ cell survival and activation was explored. RA-NLC enhanced B cell viability and inhibited spontaneous apoptosis by a mechanism that was dependent on their expression of vascular cell adhesion molecule-1 (VCAM-1, CD106) and bone marrow stromal cell antigen-1 (BST-1, CD157). RA-NLC also enhanced Ig production and promoted the outgrowth of B lymphoblastoid cell lines. These findings are consistent with the conclusion that NLC in bone marrow or in synovial tissue may play a role in the local and systemic stimulation of B cell activity characteristic of RA.

\section{Methods}

Isolation of NLC clones from RA bone marrow and synovial tissue. NLC lines were established from RA bone marrow and synovial tissue as previously described (9-11) and clones of NLC were established from these lines. In brief, heparinized bone marrow from the iliac crest or synovial tissue from knee joints of patients with RA who met American College of Rheumatology criteria (14) was obtained after informed consent. Synovial tissue was dissociated by collagenase and trypsin. Isolation of nurse-like cell lines was accomplished as described previously (9-11), by culturing dissociated single cells in DME (Bio Whittaker, Walkersville, MD) supplemented with $10 \%$ FBS (Life Technologies, Inc., Grand Island, NY) and 10\% conditioned medium. Conditioned medium for the initial culture was prepared by incubation of PBMC from 10 healthy donors $\left(1 \times 10^{6}\right.$ cells/ $\mathrm{ml}$ ) in a $75-\mathrm{cm}^{2}$ culture flask (Becton Dickinson, Mountain View, CA) in RPMI 1640 (Life Technologies, Inc.) with 10\% FBS for $48 \mathrm{~h}$ as described (9). The conditioned medium was added to the cultures twice weekly until stable cell lines were obtained. The cultures were then maintained for $>2 \mathrm{mo}$, with repeated weekly cell transfers. Afterward, the NLC lines were cloned by limiting dilution. To accomplish this, the NLC lines were adjusted to 20 cells $/ \mathrm{ml}$ in DME with $10 \%$ FBS, and $25 \mu \mathrm{l}$ ( 0.5 cells) of the cell suspension was added to individual wells of a 96-well flat-bottom microtiter plate (Becton Dickinson), and incubated at $37^{\circ} \mathrm{C}$ in $7 \% \mathrm{CO}_{2} / 93 \%$ air. The growing cells in individual wells were transferred to a 24-well flat-bottom culture plate (Becton Dickinson) containing DME with $10 \%$ FBS. Thereafter, clones were maintained and replenished with fresh DME medium with $10 \%$ FBS every $3-4$ d.

Several NLC clones were obtained from the RA patients. RANLC33BM, RA-NLC87BM, and RA-NLC91BM were from RA bone marrow, whereas RA-NLC34syn, RA-NLC45syn, RA-NLC88syn, and RA-NLC77syn were from RA synovial tissue. All these RANLCs were identified by the capacity to support pseudoemperipolesis, as indicated by the migration of $\mathrm{T}$ cells beneath them observed by phase-contrast microscopy in vitro (Fig. 1). The T cell lymphoma line, MOLT-17 (American Type Culture Collection, Rockville, MD) was used to document the capacity of the various nurse cell clones to support pseudoemperipolesis.

Other cell lines. Mouse fibroblast cell lines NIH3T3 and L cells, the human B lymphoblastoid cell line, Raji, the human B cell lymphoma lines $\mathrm{MC} / \mathrm{car}$ and RAMOS, and the human T cell lymphoma line, MOLT-17 were obtained from American Type Culture Collection. The EBV-transformed B cell lymphoblastoid cell line, ML-1, was a kind gift of Dr. Ton Logtenberg (University of Utrecht, The Netherlands). Human dermal fibroblasts (DT1) were a gift from Dr. Heather Wisbey (University of Texas Southwestern Medical Center, Dallas, Texas).

$B$ cell separation. PBMC were isolated from heparinized blood of healthy adult volunteers by centrifugation over sodium diatrizoate/ Ficoll gradients (Pharmacia Fine Chemicals, Inc., Piscataway, NJ). $\mathrm{CD} 19^{+} \mathrm{B}$ cells were purified by using the CEPRATE streptavidin column (CellPro, Bothell, WA), after staining of the cells with subsaturating concentrations of biotinylated mouse anti-human CD19 mAb (Coulter Corp., Miami, FL). The resultant population of B cells contained $>97 \% \mathrm{CD} 20^{+} \mathrm{B}$ cells.

$\mathrm{CD}^{+} \mathrm{T}$ cell separation. $\mathrm{CD} 4^{+} \mathrm{T}$ cells were prepared from B celldepleted PBMC by negative selection, using a panning technique (15) to deplete contaminating HLA-DR ${ }^{+}$cells and $\mathrm{CD} 8^{+} \mathrm{T}$ cells. Cells were reacted with saturating concentrations of the anti-HLA-DR $\mathrm{mAb}, \mathrm{L} 243$, and the anti-CD8mAb, OKT8 (both from American Type Culture Collection). After being washed, the cells were incubated on goat anti-mouse Ig (GaMIg) (Cappel Laboratories, Inc., Cochranville, PA) coated panning dishes. After a 70-min incubation at $4^{\circ} \mathrm{C}$, the nonadherent cells were gently aspirated and were panned a second time on another GaMIg-coated panning dish, after which the nonadherent cells were aspirated. The $\mathrm{CD}^{+} \mathrm{T}$ cell population obtained in this manner contained $<0.1 \%$ esterase-positive cells, $<1 \%$ $\mathrm{CD}^{+} \mathrm{T}$ cells, and $>96 \% \mathrm{CD} 4^{+} \mathrm{T}$ cells.

Antibodies, cytokines, and reagents. Various antibodies were used, including a goat $\mathrm{F}\left(\mathrm{ab}^{\prime}\right)_{2} \mathrm{Ab}$ directed to human $\mathrm{IgD}$ (Caltag Laboratories, Burlingame, $\mathrm{CA}$ ); a control goat $\mathrm{F}\left(\mathrm{ab}^{\prime}\right)_{2} \mathrm{Ab}$ (Caltag Laboratories); Leu-20, a phycoerythrin (PE)-conjugated mouse $\mathrm{IgG}_{1}$ $\mathrm{mAb}$ directed to human CD23 (Becton Dickinson, San Jose, CA); A1A5, a mouse $\operatorname{IgG}_{1} \mathrm{mAb}$ directed to human CD29 (integrin $\beta 1$ ) (Cosmo Bio, Tokyo, Japan); Ber-MAC-DRC, a mouse $\operatorname{IgG}_{1} \mathrm{mAb}_{\text {di- }}$ rected to human CD35 (Dako Corp., Carpinteria, CA); HB-7, a FITC-conjugated mouse $\mathrm{IgG}_{1} \mathrm{mAb}$ directed to human $\mathrm{CD} 38$ (Caltag Laboratories); a control FITC-conjugated mouse $\mathrm{IgG}_{1} \mathrm{mAb}_{\text {(Caltag }}$ Laboratories); G28.5, a mouse $\mathrm{IgG}_{1} \mathrm{mAb}$ directed to human CD40 (American Type Culture Collection); 4D9-8, a mouse $\mathrm{IgG}_{1} \mathrm{mAb}$ against the human CD40 ligand molecule (a kind gift of Dr. R.J. Noelle, Dartmouth Medical School); P1B5, a mouse $\mathrm{IgG}_{1} \mathrm{mAb}_{\text {directed }}$ to human CD49c (Funakoshi, Tokyo, Japan); HP2/1, a mouse $\mathrm{IgG}_{1}$ $\mathrm{mAb}$ directed to human $\mathrm{CD} 49 \mathrm{~d}(\alpha 4$ integrin) (Immunotech, Marseilles, France); 15.2, a mouse $\mathrm{IgG}_{1} \mathrm{mAb}$ directed to human CD54 (Cosmo Bio, Tokyo, Japan); TP/55.3.1, a FITC-conjugated mouse $\operatorname{IgG}_{2 \mathrm{a}} \mathrm{mAb}$ directed to human CD69 (Caltag Laboratories); a control FITC-conjugated mouse $\mathrm{IgG}_{2 \mathrm{a}} \mathrm{mAb}$ (Caltag Laboratories); 38-13, a rat IgM mAb directed to human CD77 (Cosmo Bio); B70, a PE-conjugated mouse $\mathrm{IgG}_{2 \mathrm{~b}} \mathrm{mAb}$ directed to human CD86 (PharMingen, San Diego, CA); a control PE-conjugated mouse $\operatorname{IgG}_{2 \mathrm{~b}} \mathrm{mAb}$ (PharMingen); DX2, a mouse $\mathrm{IgG}_{1} \mathrm{mAb}$ directed to human CD95 (PharMingen); 51-10C9, a mouse $\mathrm{IgG}_{1} \mathrm{mAb}$ directed to human CD106 (VCAM-1) (PharMingen) for staining; 1.G11B1, a mouse $\mathrm{IgG}_{1} \mathrm{mAb}$ directed to human CD106 (Serotec, Oxford, England) for blocking; MOPC, a control mouse $\mathrm{IgG}_{1} \mathrm{mAb}$; MB40.5 (American Type Culture Collection), a mouse $\mathrm{IgG}_{1} \mathrm{mAb}$ directed to human HLA-A,B,C (class I MHC); L243 (American Type Culture Collection), a mouse $\operatorname{IgG}_{2 \mathrm{a}} \mathrm{mAb}$ directed to monomorphic HLA-DR deter- 
minants (class II MHC); a sheep anti-mouse $\operatorname{IgG}_{1}$ FITC conjugate (The Binding Site, Birmingham, UK); a control FITC-conjugated mouse $\mathrm{IgG}_{1} \mathrm{mAb}$ (Caltag Laboratories); BEC7, a mouse $\mathrm{IgG}_{1} \mathrm{mAb}$ against human CD157; RF3, a mouse $\operatorname{IgG}_{2 a}$ mAb against human CD157; RS38, a mouse IgM mAb against human BST-2 (Medical and Biological Laboratories Co., Ltd., Nagoya, Japan); polyclonal rabbit $\mathrm{Ab}$ against human $\mathrm{CD} 157$; control preimmune rabbit $\mathrm{Ab}$. BEC7, $\mathrm{RF} 3$, polyclonal rabbit Ab against human CD157, and control preimmune rabbit $\mathrm{Ab}$ were developed and purified as described previously (16-19). FITC-conjugated sheep $\mathrm{F}\left(\mathrm{ab}^{\prime}\right)_{2} \mathrm{Ab}$ directed to mouse IgG heavy- and light-chain (Calbiochem, La Jolla, CA) was used as secondary antibody.

Soluble forms of human recombinant CD157 and CD38 were produced and purified as described previously (19). CD157 and CD38 are $\sim 30 \%$ homologous at the amino acid level and appear to have derived by gene duplication from an ancestral gene (20-22). Purified recombinant human IFNy (Shionogi and Co., Ltd., Osaka, Japan) was used at $100 \mathrm{U} / \mathrm{ml}$ for stimulation of RA-NLC or human dermal fibroblasts (DT1).

Quantitation of cytokines. RA-NLCs were maintained routinely with DME supplemented with $10 \%$ FBS until they became confluent. The culture supernatant of each clone was collected, and the amount of IL-1 $\alpha$, IL-1 $\beta$, IL-2, IL-3, IL-4, IL-6, IL-7, IL-8, granulocyte colonystimulating factor (G-CSF), granulocyte-macrophage CSF (GM-CSF), TNF- $\alpha$, and TNF- $\beta$ was measured with ELISA kits (Quantikine; R \& D Systems, Minneapolis, MN), according to the manufacturer's instructions.

Culture medium. B cell lines, Raji, RAMOS, and normal peripheral B cell were cultured in RPMI 1640 medium (Life Technologies, Inc.) supplemented with $200 \mathrm{U} / \mathrm{ml}$ penicillin $\mathrm{G}, 10 \mu \mathrm{g} / \mathrm{ml}$ gentamicin, $0.3 \mathrm{mg} / \mathrm{ml} \mathrm{L}$-glutamine, and 10\% FBS (Life Technologies, Inc.). RANLC and fibroblast cell lines DT1, NIH3T3, and L cells, were cultured in high-glucose DME (Bio Whittaker) with $100 \mathrm{U} / \mathrm{ml}$ penicillin $\mathrm{G}, 10 \mu \mathrm{g} / \mathrm{ml}$ gentamicin, $0.3 \mathrm{mg} / \mathrm{ml} \mathrm{L}$-glutamine, and 10\% FBS (Life Technologies, Inc.).

Flow cytometric analysis. The cells were cultured for various lengths of time with various stimuli as indicated and after washing with PBS containing $2 \%$ normal human $\mathrm{AB}$ serum and $0.1 \%$ sodium azide, cells were reacted with saturating concentrations of various $\mathrm{mAb}$ at $4^{\circ} \mathrm{C}$ for $30 \mathrm{~min}$. Analysis was performed using the FACScan (Becton Dickinson) flow cytometer. Dead cells were eliminated by propidium iodide staining. Density of staining was expressed as the change in mean fluorescence intensity $(\Delta \mathrm{MFI})$ for staining with the $\mathrm{mAb}$ of interest calculated by subtracting the MFI of staining with the control mAb.

RNA extraction, $C D N A$ synthesis, and PCR analysis. RNA was isolated using the SNAP-O-SOL RNA/DNA isolation kit obtained from Biotecx Laboratories (Houston, TX). After quantification of isolated RNA by spectrophotometry, cDNA was synthesized by priming with $500 \mathrm{ng}$ oligo dT (Pharmacia, Alameda, CA) in Ultraspec diethylpyrocarbonate water (Biotecx Laboratories), $5 \mathrm{mM}$ DTT, $0.5 \mathrm{mM}$ dNTP, $50 \mathrm{mM}$ Tris- $\mathrm{HCl}(\mathrm{pH} 8.3), 75 \mathrm{mM} \mathrm{KCl}$, and $3 \mathrm{mM}$ $\mathrm{MgCl}_{2}$ by using $200 \mathrm{U}$ Superscript reverse transcriptase (Life Technologies, Gaithersburg, MD) per $1 \mu \mathrm{g}$ of total RNA. Each PCR reaction was performed with 50-100 ng of cDNA in a 100- $\mu$ l vol containing Ultraspec water (Cinna-Biotecx), $50 \mathrm{mM} \mathrm{KCl}, 10 \mathrm{mM}$ Tris- $\mathrm{Cl}$ ( $\mathrm{pH}$ 9.0), $0.001 \%$ gelatin (wt/vol), $200 \mu \mathrm{M}$ of each dNTP, $1.5 \mathrm{mM} \mathrm{MgCl}$, and $0.3 \mu \mathrm{M}$ of each primer. A lower layer of dNTPs, $\mathrm{MgCl}_{2}$, and primers was separated from an upper layer of Taq polymerase, cDNA, and $10 \times$ PCR buffer (KCI, Tris-Cl, and gelatin) by an AmpliWax PCR Gem 100 pellet (Perkin-Elmer Corp., Norwalk, CT). The upper layer was added just before the start of amplification. After a 5 -min denaturation step at $94^{\circ} \mathrm{C}, 35-40$ cycles of amplification were used with the following temperature program: 1 min of denaturation at $94^{\circ} \mathrm{C}, 1.5 \mathrm{~min}$ at the annealing temperature for the specific primer pair, and $2 \mathrm{~min}$ of extension at $72^{\circ} \mathrm{C}$. The primers used for the PCR analysis have been published $(16,23-29)$. PCR products were resolved by electrophoresis on a $1 \%$ agarose gel in $0.5 \times$ Tris boric acid
EDTA. After denaturation of the gel in $1.5 \mathrm{M} \mathrm{NaCl}$ and $0.5 \mathrm{M} \mathrm{NaOH}$ for $30 \mathrm{~min}$, the PCR products were transferred onto a nylon membrane (Zetaprobe GT; Biorad, Hercules, CA) using a vacuum-blotting apparatus. The membrane was baked at $80^{\circ} \mathrm{C}$ for $30 \mathrm{~min}$ before screening with a ${ }^{32} \mathrm{P}-5^{\prime}$ end-labeled probe, specific for PCR products amplified with a given primer pair. Hybridization was conducted in $5 \times$ SSC, $20 \mathrm{mM} \mathrm{Na}_{2} \mathrm{HPO}_{4}, 7 \%$ SDS, $1 \times$ Denhardt's solution with 100 $\mu \mathrm{g} / \mathrm{ml}$ denatured salmon sperm DNA at $42^{\circ} \mathrm{C}$. Blots were washed in $5 \times \mathrm{SSC}-0.1 \%$ SDS at room temperature for $20 \mathrm{~min}$ and in $1 \times \mathrm{SSC}-$ $0.1 \%$ SDS at $42^{\circ} \mathrm{C}$ for 15 min and subjected to autoradiography.

Analysis of viable cells. B cells $\left(2 \times 10^{5}\right)$ were cultured in medium alone or with RA-NLC or fibroblasts in 96-well flat-bottom plates (Costar, Cambridge, MA) for several days and gently resuspended and harvested from the wells. Numbers of viable cells were counted using a hemocytometer, excluding dead cells by staining with trypan blue. For each experiment, the mean \pm SEM of the total number of cells cultured in nine wells was calculated. For time-course experiments, each experiment was carried out in duplicate, and the mean was calculated.

Flow cytometric analysis of apoptosis. Apoptosis was analyzed using the flow cytometric TUNEL method (30). Briefly, $8 \times 10^{5}$ cells were harvested, washed in PBS, and fixed in $1 \%$ paraformaldehyde for $20 \mathrm{~min}$ on ice. Cells were washed in PBS, resuspended, and stored in $70 \%$ ice-cold ethanol. For analysis, the APO-BRDU kit from Phoenix Flow (San Diego, CA) was used according to the manufacturer's protocol. Cells $\left(1 \times 10^{4}\right)$ were analyzed by flow cytometry with a FACScan (Beckon Dickinson) using a 50\% logarithmic contour graph with the intensity of propidium iodine staining displayed on the horizontal axis and Br-dUTP-FITC on the vertical axis. For the negative control and to set the initial gate, B cells in medium alone, were analyzed without the addition of TdT. The percentage of apoptosis was based on the increase in TdT-mediated incorporation of BrdUTP.

Measurement of Ig production. At the end of $12 \mathrm{~d}$ of incubation, the supernatants from each culture well were collected and assayed for Ig content. Ig in the culture supernatants was quantitated by isotype-specific ELISA as previously described (31). Briefly, microtiter plates (Cooke; Dynatech Laboratories, Alexandria, VA) were coated with affinity-purified goat antibodies to human $\alpha, \mu$, or $\gamma$ chains (Tago, Camarillo, CA) diluted in borate-buffered saline by incubating at $37^{\circ} \mathrm{C}$ for $2 \mathrm{~h}$ and kept at $4^{\circ} \mathrm{C}$ overnight. Plates were then washed with Tween saline and incubated with serial dilutions of standard Ig preparation (IgA and IgG; Behring Diagnostics, La Jolla, CA; IgM, Tago) or appropriately diluted culture supernatants in PBS containing $0.5 \%$ Tween 20 (Sigma Chemical Co., St. Louis, MO) at $37^{\circ} \mathrm{C}$ for $2 \mathrm{~h}$. Bound Ig was detected with peroxidase-conjugated affinity-purified isotype-specific Abs (Tago) and $o$-phenylenediamine dihydrochloride (Sigma Chemical Co.) as substrate. Absorbance was determined at $490 \mathrm{~nm}$ on the EL312 Biokinetics Reader (Bio-Tek Instruments, Winooski, VT). The amount of Ig in the supernatants was calculated by comparison with a standard curve by using the KinetiCalc program (Bio-Tek Instruments, Inc.). Triplicates for each culture condition were performed and differed by $<10 \%$. The sensitivities of the specific assays were $12 \mathrm{ng} / \mathrm{ml}$ for $\operatorname{IgA}$ and $\mathrm{IgG}$, and 24 $\mathrm{ng} / \mathrm{ml}$ for IgM.

Limited dilution analysis of B cell outgrowth. To estimate the number of precursors of EBV-transformed B cells in peripheral blood, limiting dilution frequency analysis was performed. Various numbers of peripheral B cells from four different donors were cultured with RA-NLC91BM for 4 wk in 96-well flat-bottomed plates. Nine replicates of each cell dilution were carried out and the percentage of wells yielding B cell growth was calculated.

Assay of cell proliferation. To assay cellular proliferation, a colorimetric method was used (32). Briefly, B cells were cultured for the indicated length of time, after which $180 \mu$ l of the supernatant was removed without disturbing the pellet. $10 \mu \mathrm{l}$ of a yellow tetrazolium salt, MTT (3-[4,5-dimethylthiazol-2-yl]-2,5-diphenyl tetrazolium bromide; Sigma Chemical Co.), and $100 \mu$ l of PBS were added to the re- 
maining pellet and incubated at $37^{\circ} \mathrm{C}$ for $4 \mathrm{~h}$, after which $100 \mu \mathrm{l}$ of $0.1 \mathrm{~N}$ $\mathrm{HCl} /$ isopropanol alcohol was added to terminate the reaction and dissolve the formazan product. The contents of the well were then pipetted gently until mixed, and the absorbance was read at 570 and $630 \mathrm{~nm}$ on the EL312 Biokinetics Reader.

\section{Results}

Establishment of the RA-NLC clones. Seven clones were established from RA-NLC parental lines from different RA patients, three from bone marrow (RA-NLC33BM, RANLC87BM, and RA-NLC91BM), and four from synovial tissue (RA-NLC34syn, RA-NLC45syn, RA-NLC88syn, and RA-NLC77syn). The appearance of a representative clone, RA-NLC34syn, is shown in Fig. $1 a$. RA-NLCs were large adherent cells with an irregular polygonal shape, long dendritic processes, and rich cytoplasm. They did not exhibit either a typical fibroblastic (slender and elongated) or macrophagelike appearance (irregular with many membrane ruffles). Each of the clones was similar in appearance to NLC lines derived from bone marrow and synovium and previously described (911; Takeuchi, E., T. Tomita, T. Toyosaki-Maeda, H. Hashimoto, M. Kaneko, H. Takano, K. Sugamoto, R. Suzuki, and T. Ochi, manuscript submitted for publication; Tomita, T., E. Takeuchi, T. Toyosaki-Maeda, H. Oku, M. Kaneko, H. Takano, K. Sugamoto, K. Ohzono, R. Suzuki, and T. Ochi, manuscript submitted for publication).

All RA-NLC clones were screened for the ability to promote pseudoemperipolesis. RA-NLCs were incubated with the human T cell lymphoma line, MOLT-17, and their ability to induce MOLT-17 cells to migrate beneath them was exam-

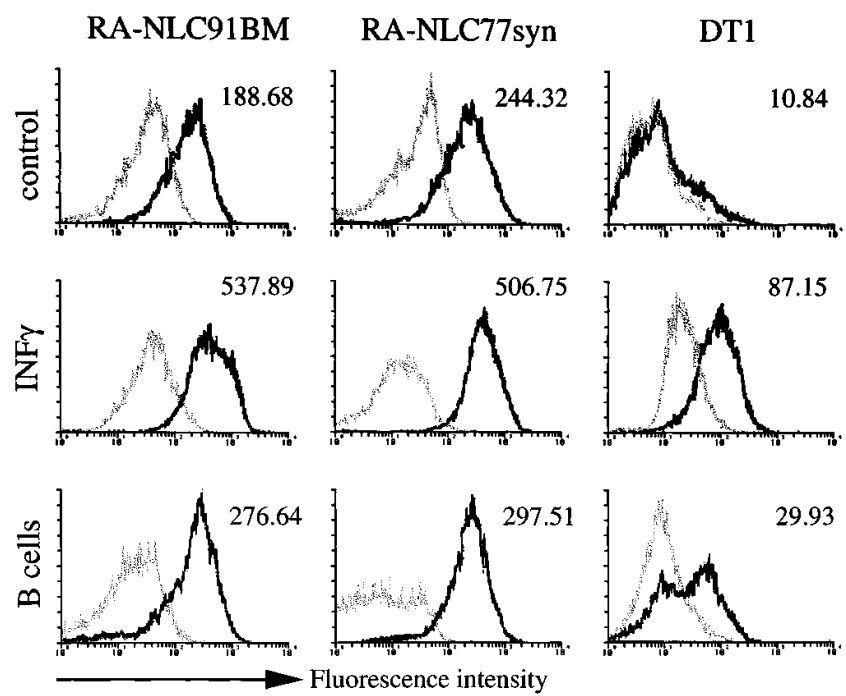

Figure 2. Expression of CD106 by RA-NLC and fibroblasts. Two RA-NLC cell lines and DT1 were cultured in medium alone or with IFN $\gamma(100 \mathrm{U} / \mathrm{ml})$ or with $2 \times 10^{6}$ peripheral B cells for $3 \mathrm{~d}$. Numbers in each histogram indicate the $\Delta$ MFI for staining with anti-CD106 $\mathrm{mAb}$ calculated by subtracting the MFI of staining with an isotypematched control mAb.

ined by phase-contrast microscopy (Fig. 1c). As previously reported for thymic nurse cells and skin-derived NLC $(6,9)$, and noted for RA-derived nurse-like cell lines $(10,11)$, MOLT-17 cells were induced to undergo pseudoemperipolesis by the hu-

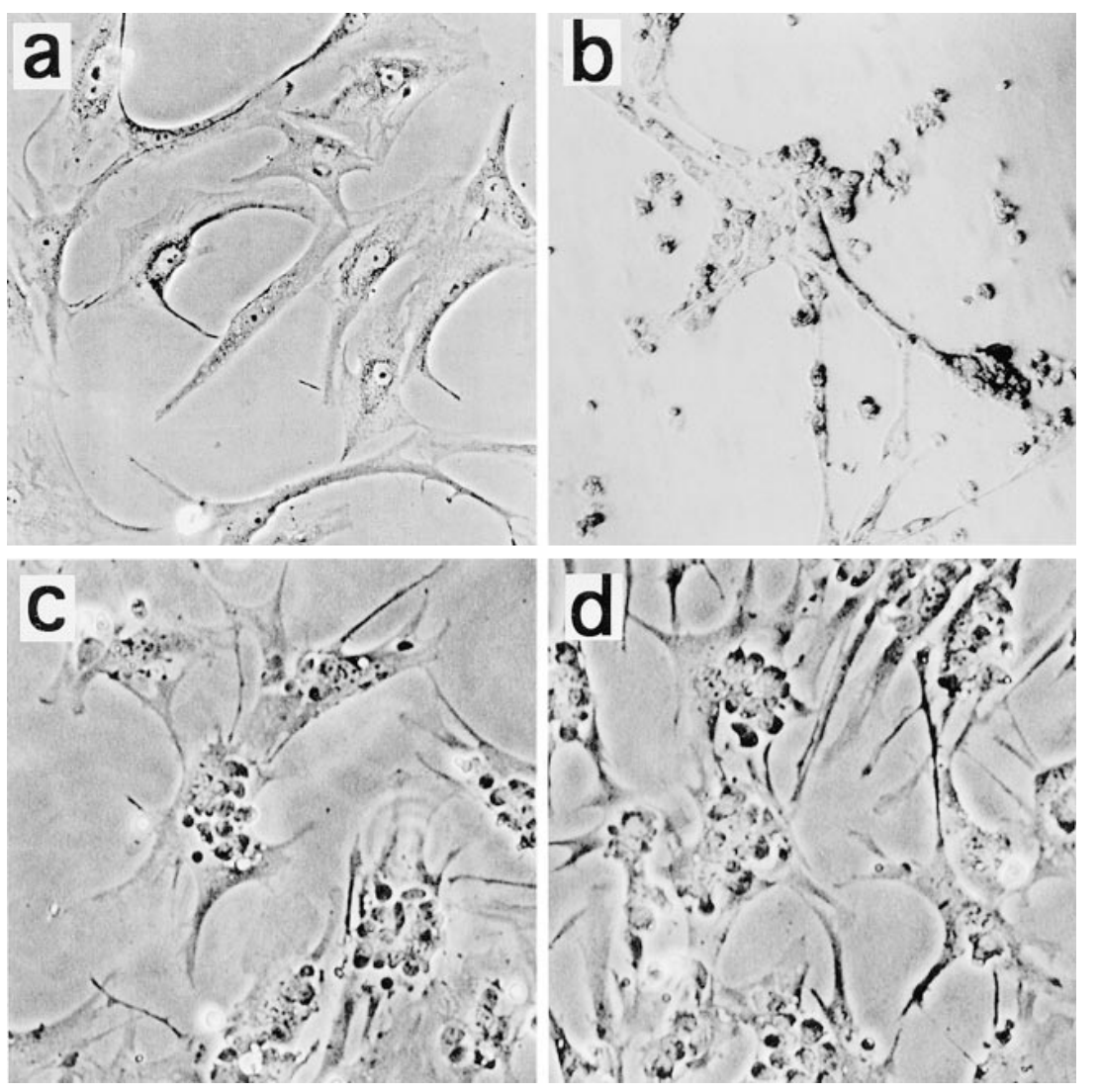

Figure 1. RA-NLC induce pseudoemperipolesis of $\mathrm{B}$ and $\mathrm{T}$ lymphoma cells and bind peripheral $B$ cells. The morphologic appearance of RANLC34syn is shown by phase-contrast microscopy when cultured alone $(a)$, with normal peripheral B cells for $4 \mathrm{~d}(b)$, or with the $\mathrm{T}$ cell lymphoma line, MOLT-17 (c), or the B cell lymphoma line, $\mathrm{MC} / \mathrm{car}(d) . \times 200$. 


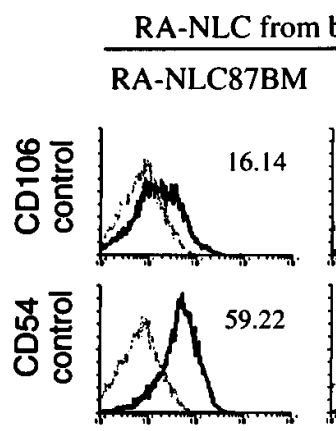

RA-NLC from synovial tissue

RA-NLC77syn

RA-NLC88syn

dermal fibroblasts

DT1
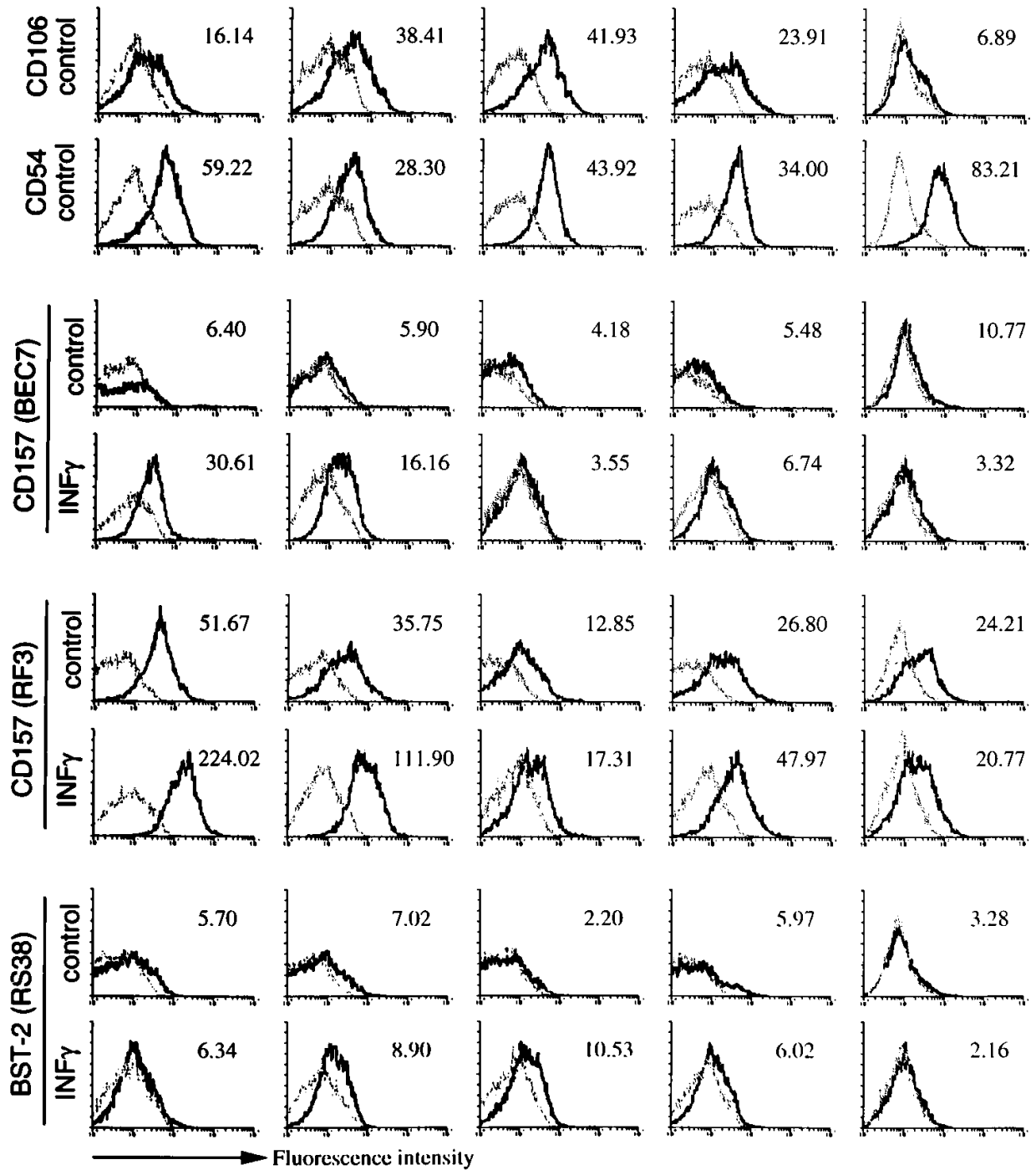

Figure 3. CD106, CD54, CD157, and BST-2 expression by RA-NLC cells and fibroblasts. Four RA-NLC cell lines or human dermal fibroblasts (DT1) were cultured in medium alone (control) or with IFN $\gamma$ $(100 \mathrm{U} / \mathrm{ml})$ for $3 \mathrm{~d}$, and were detached with $0.05 \%$ trypsin-EDTA in PBS at room temperature for $5 \mathrm{~min}$. They were then stained with various mAbs, and analyzed by FACScan. For the staining of CD157, two different $\mathrm{mAbs}, \mathrm{BEC} 7$ and RF3, were used. Numbers in each histogram indicate the $\triangle$ MFI for staining with anti-CD106, CD54, CD157 (BST-1), or BST-2 mAb calculated by subtracting the MFI of staining with an isotype-matched control $\mathrm{mAb}$. Controls are RA-NLC or DT1 cultured in medium alone.

man RA-NLC clones, forming typical clusters and, thereby, permitting the RA-NLC clones to be classified functionally as nurse cells and not fibroblasts (9-11; Takeuchi, E., T. Tomita, T. Toyosaki-Maeda, H. Hashimoto, M. Kaneko, H. Takano, K. Sugamoto, R. Suzuki, and T. Ochi, manuscript submitted for publication; Tomita, T., E. Takeuchi, T. Toyosaki-Maeda, H. Oku, M. Kaneko, H. Takano, K. Sugamoto, K. Ohzono, R. Suzuki, and T. Ochi, manuscript submitted for publication). The B cell lymphoma line, MC/car also migrated under RA-NLCs (Fig. $1 d$ ). Of note, peripheral B cells from normal donors bound to RA-NLCs (Fig. $1 \mathrm{~b}$ ) but did not migrate beneath them. Peripheral B cells were 14- to 20-fold smaller than RANLCS B cells, and primarily bound to the processes of RANLC. Despite the binding of peripheral B cells to RA-NLCs, there was no obvious pseudoemperipolesis by these cells. All of the RA-NLC clones interacted with MOLT-17, Mc/car, and peripheral B cells comparably.
Surface phenotype of RA-NLC. RA-NLC clones from bone marrow and synovial tissue expressed CD29, CD49c, CD54, CD106, and HLA-A,B,C (class I MHC) constitutively, but did not express CD35, CD40, or CD40L (Figs. 2 and 3; Table I). Human dermal fibroblasts also expressed CD29, CD49c, CD54, and class I MHC, whereas constitutive expression of CD106 was minimal. IFN $\gamma(100 \mathrm{U} / \mathrm{ml})$ stimulation of RA-NLC induced expression of CD40 and HLA-DR (class II MHC), but not expression of CD35 or CD154/CD40L (Table I).

Expression of CD106 by RA-NLCs was modestly enhanced by culture with normal peripheral B cells, and markedly enhanced by IFN $\gamma$. In contrast, expression of CD106 by human dermal fibroblasts was much less marked after stimulation with IFN $\gamma$ or by culture with peripheral B cells (Fig. 2).

Expression of CD157(BST-1) and BST-2, which are molecules that can support the growth of murine pre-B cell lines (16-18), was also examined (Fig. 3). Using mAb RF3, expres- 


\begin{tabular}{|c|c|c|c|c|c|c|c|}
\hline \multirow{3}{*}{$\begin{array}{c}\text { Surface } \\
\text { determinant }\end{array}$} & & \multicolumn{5}{|c|}{ RA-NLC } & \multirow[b]{3}{*}{ Human skin fibroblasts (DT1) } \\
\hline & & \multicolumn{2}{|c|}{ Bone marrow } & \multicolumn{3}{|c|}{ Synovial tissue } & \\
\hline & & $87 \mathrm{BM}$ & $91 \mathrm{BM}$ & 77syn & 88syn & 45 syn & \\
\hline $\mathrm{CD} 29$ & Resting & + & + & + & + & + & + \\
\hline \multirow[t]{2}{*}{ CD35 } & Resting & - & - & - & - & - & - \\
\hline & $\mathrm{IFN} \gamma$ & - & - & - & - & - & - \\
\hline \multirow[t]{2}{*}{$\mathrm{CD} 40$} & Resting & - & - & - & - & - & - \\
\hline & $\mathrm{IFN} \gamma$ & + & + & + & + & + & + \\
\hline \multirow[t]{2}{*}{$\mathrm{CD} 40 \mathrm{~L}$} & Resting & - & - & - & - & - & - \\
\hline & $\mathrm{IFN} \gamma$ & - & - & - & - & - & - \\
\hline $\mathrm{CD} 49 \mathrm{c}$ & Resting & + & + & + & + & + & + \\
\hline CD54 & Resting & + & + & + & + & + & + \\
\hline \multirow[t]{2}{*}{ CD106 } & Resting & + & + & + & + & + & $-1+$ \\
\hline & $\mathrm{IFN} \gamma$ & + & + & + & + & + & + \\
\hline HLA-A,B,C & Resting & + & + & + & + & + & + \\
\hline \multirow{2}{*}{ HLA-DR } & Resting & - & - & - & - & - & - \\
\hline & $\mathrm{IFN} \gamma$ & + & + & + & + & + & + \\
\hline
\end{tabular}

RA-NLC or human skin fibroblasts (DT1) were cultured with medium alone (resting) or with IFN $\gamma$ (100 U/ml) for 3 d, and were detached with $0.05 \%$ trypsin-EDTA in PBS at room temperature for $5 \mathrm{~min}$. They were stained with anti-human $\mathrm{mAb}$, and analyzed by FACScan.

sion of CD157 was detected on all RA-NLCs, as well as on human dermal fibroblasts (DT1). Expression of CD157 by RANLCs, but not dermal fibroblasts, was enhanced by IFN $\gamma$. This was much more marked with bone marrow-derived compared with synovium-derived RA-NCL. Using mAb BEC7, only RA-NLC87BM and RA-NLC91BM were found to express CD157 and then only after stimulation with IFN $\gamma$. Even after IFN $\gamma$ stimulation expression of BEC7-identified CD157 was modest. BST-2 was not expressed by any of the cells constitutively, and IFN $\gamma$ enhanced expression minimally and only by some clones. It should be noted that expression of CD106 and CD157 mRNA was found in all RA-NLC clones by reverse transcription (RT)-PCR (data not shown). To assure that RANLCs had not been transformed by EBV, mRNA for the EBV-encoded gene, BamW was also examined. All RA-NLCs and DT1 were negative for mRNA for this EBV gene product (data not shown).

Cytokine production by RA-NLC. The capacity of RANLC to produce various cytokines was studied. Table II shows cytokines produced by RA-NLC33BM from bone marrow and
RA-NLC34syn from synovial tissue. RA-NLC from bone marrow produced detectable levels of IL-6, IL-7, IL-8, and GMCSF, and the production of IL- 8 was very great. RA-NLC from synovial tissue produced detectable levels of IL-6, IL-8, G-CSF, and GM-CSF proteins, and the production of IL-6 and IL-8 was very great. Bone marrow-derived, but not synovial RA-NLC produced IL-7, whereas synovial RA-NLC produced G-CSF and greater amounts of IL-6.

$R A-N L C$ support the survival of peripheral $B$ cells by blocking spontaneous apoptosis. Peripheral B cells were cultured in medium alone or with RA-NLC or fibroblasts, and the number of viable $\mathrm{B}$ cells was estimated by trypan blue exclusion (Fig. 4). B cells cultured in medium alone rapidly died (6.2\% viable at day $6,3.4 \%$ viable at day $9,1.4 \%$ viable at day 14 , and 0 viable at day 21). Coculture of B cells with NIH3T3 or L cells had little effect on viability. By contrast, culture of B cells with RA-NLC markedly increased their viability $(41.9 \%$ viable at day $6,31.4 \%$ viable at day $9,14.9 \%$ viable at day 14 , and $3.7 \%$ viable at day 21$)$. DT1 also supported B cell viability, but less effectively than RA-NLC. The loss of viability of B

Table II. Cytokines Secreted by RA-NLC

\begin{tabular}{lcccccccccccc}
\hline & IL-1 $\alpha$ & IL-1 $\beta$ & IL-2 & IL-3 & IL-4 & IL-6 & IL-7 & IL-8 & G-CSF & GM-CSF & TNF $\alpha$ & TNF $\beta$ \\
\hline $\begin{array}{l}\text { RA-NLC from bone marrow } \\
\text { (RA-NLC33BM) }\end{array}$ & $<0.5$ & $<10.0$ & $<40.0$ & $<7.0$ & $<0.5$ & 17.0 & 14.5 & 7876.0 & $<10.0$ & 3.0 & $<0.5$ & $<0.5$ \\
$\begin{array}{l}\text { RA-NLC from synovial tissue } \\
\text { (RA-NLC34syn) }\end{array}$ & $<0.5$ & $<10.0$ & $<40.0$ & $<7.0$ & $<0.5$ & 1365.0 & $<0.5$ & 1395.5 & 113.5 & 5.5 & $<0.5$ & $<0.5$ \\
\hline
\end{tabular}

RA-NLC were cultured in 24-well plates with DME plus 10\% FBS to confluence. After changing the medium, RA-NLC were cultured for $7 \mathrm{~d}$ and supernatant was obtained. Cytokines in supernatant were measured with ELISA and expressed as picograms per milliliter. Data are shown from one of two experiments with similar results. 


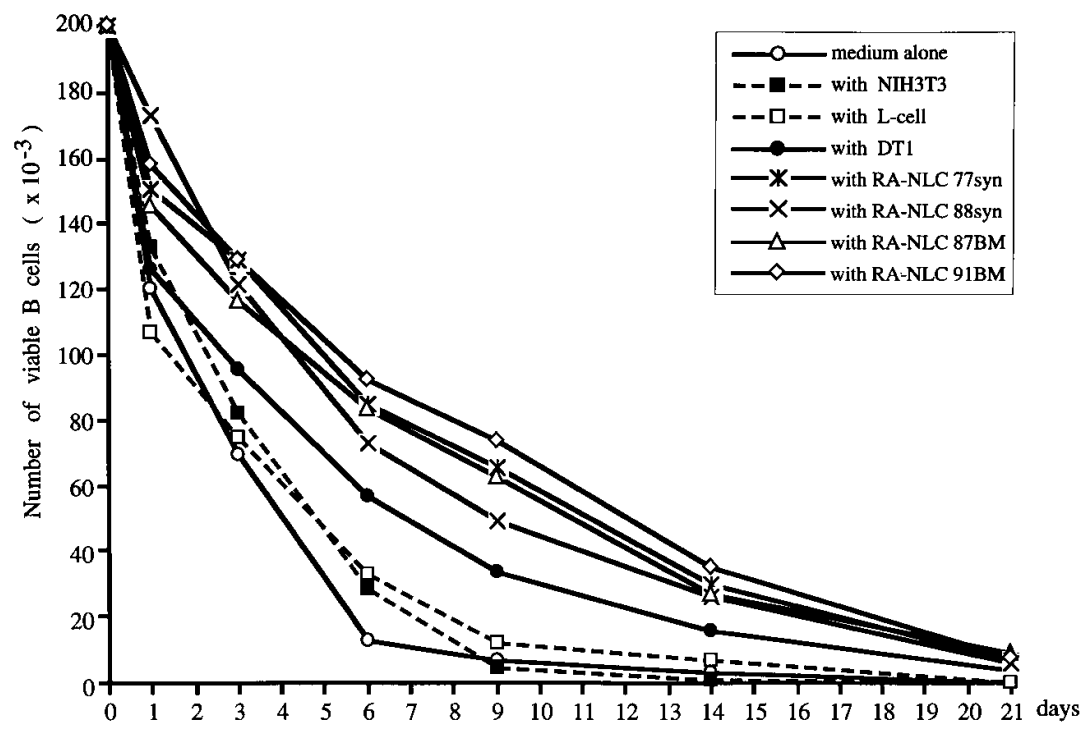

Figure 4. RA-NLC promote survival of peripheral B cells more effectively than fibroblasts. Peripheral B cells $\left(2 \times 10^{5}\right)$ were cultured in medium alone or with RA-NLC or mouse fibroblasts (NIH3T3, L cell) or human dermal fibroblasts (DT1) for $21 \mathrm{~d}$, and the numbers of viable cells were counted at days $1,3,6,9,14$, and 21 by trypan blue exclusion. Each experiment was carried out in duplicate, and the graph shows mean of the number of viable cells. The percentage of viable cells was calculated by dividing the number of viable cells on each day by the initial cell number $\left(2 \times 10^{5}\right)$. The percentages at day 6 with RA-NLC, $41.9 \pm 2.0 \%$ (mean \pm SEM); DT1, $28.4 \%$; medium alone, $6.2 \%$, and at day 9, RA-NLC, $31.4 \pm 2.5 \%$; DT1, $16.8 \%$; medium alone $3.4 \%$, and at day 14 , RA-NLC, $14.9 \pm 1.0 \%$; DT1, $7.8 \%$; medium alone $1.4 \%$, and at day 21 , RA-NLC, $3.7 \pm 0.3 \%$; DT1, $1.8 \%$; medium alone, none.

cells cultured alone related to the induction of apoptosis, as Fig. 5 shows. Coculture of B cells with RA-NLC substantially blocked spontaneous apoptosis of peripheral B cells.

Effect of CD106 and CD157 expressed by RA-NLC on the survival of peripheral $B$ cells. The effect of CD157 on the survival of peripheral $B$ cells was examined using a soluble recombinant form of CD157 (17). Since CD157 has an 30\% amino acid sequence homology with CD38, and both CD157 and CD38 have ADP-ribosyl cyclase and cADPR hydrolase activities $(18,20-23,33-35)$, a soluble recombinant form of CD38 was used as a control. As Table III shows, only $17.6 \%$ of $B$ cells cultured in medium alone survived in culture for $5 \mathrm{~d}$, and neither soluble CD157 alone (16.9\%) nor soluble CD38
(15.8\%) affected peripheral B cell survival. By contrast, peripheral B cells cultured with RA-NLC91BM, which express both CD106 and CD157, exhibited significantly greater survival $(45.2 \%, P<0.0001)$. B cell survival promoted by RANLC91BM was reduced by a blocking anti-CD106 mAb $(18.2 \%, P<0.0001)$ to the same level of B cells cultured in medium alone $(17.6 \%)$. B cell survival promoted by RA-NLC was also reduced by a blocking anti-CD157 polyclonal $\mathrm{Ab}$ (27.3\%, $P<0.01)$, but not by the anti-CD157 mAb (RF3) used for staining. Soluble CD157, but not soluble CD38, together with RA-NLC further increased survival of B cells $(73.8 \%, P<$ 0.0001).

The effect of anti-CD106 mAb or anti-CD157 on the pro-

Table III. Effect of CD106 and CD157 on the Survival of Peripheral B Cells

\begin{tabular}{|c|c|c|c|c|}
\hline \multirow[b]{2}{*}{$\mathrm{B}$ cells with medium alone } & \multirow{2}{*}{$\frac{\text { RA-NLC }}{-}$} & \multicolumn{2}{|c|}{$\begin{array}{c}\text { Viable cells } \\
\left(\text { mean } \pm \text { SEM }\left[\times 10^{3}\right]\right)\end{array}$} & $P$ \\
\hline & & $35.2 \pm 5.7$ & $(17.6 \%)$ & \\
\hline + Soluble CD157 & - & $33.9 \pm 4.9$ & $(16.9 \%)$ & | \\
\hline + Control soluble CD38 & - & $31.6 \pm 4.2$ & $(15.8 \%)$ & $<0.0001$ \\
\hline B cells with RA-NLC cells & + & $90.5 \pm 5.6^{*}$ & $(45.2 \%)=$ & \\
\hline + Anti-CD106 mAb (1.G11B1) & + & $36.4 \pm 5.5^{*}$ & $(18.2 \%)\rceil<00001$ & \\
\hline + Control IgG1 mAb (MOPC) & + & $78.8 \pm 6.0$ & $(39.4 \%)^{\prime}<$ & \\
\hline + Anti-CD157 mAb (RF3) & + & $82.4 \pm 5.8$ & $(41.2 \%)$ & \\
\hline+ Control IgG2a mAb (P1.17) & + & $81.8 \pm 4.9$ & $(40.9 \%)$ & $<0.0001$ \\
\hline + Anti-CD157 polyclonal Ab & + & $54.6 \pm 6.3^{*}$ & $(27.3 \%)_{k}$ & \\
\hline+ Control preimmune rabbit IgG & + & $77.8 \pm 4.5$ & $(38.9 \%)\rfloor<$ & \\
\hline + Soluble CD157 & + & $147.6 \pm 8.3^{*}$ & $(73.8 \%)$ & \\
\hline + Control soluble CD38 & + & $79.0 \pm 5.1$ & $(39.5 \%)]<0.0001$ & \\
\hline
\end{tabular}

Peripheral B cells were cultured in 96-well flat-bottom culture plates $\left(2 \times 10^{5} /\right.$ well, $\left.200 \mu \mathrm{l}\right)$ in medium alone or with soluble CD157 or with control soluble CD38 for $5 \mathrm{~d}$, or with RA-NLC91BM and with several antibodies or soluble molecules indicated. MOPC (IgG $)$ was used as the isotypematched control mAb for anti-CD106 mAb, P1.17 ( $\left.\operatorname{IgG}_{2 \mathrm{a}}\right)$ was used as the isotype-matched control mAb for anti-CD157 mAb (RF3), and preimmune rabbit IgG was used as the control for polyclonal antibody to CD157. Soluble CD157 and soluble CD38 were used at $10 \mu \mathrm{g} / \mathrm{ml}$, and antibodies were used at $4 \mu \mathrm{g} / \mathrm{ml}$. The number of viable B cells was quantitated at day 5 after staining with trypan blue. Each experiment was carried out in replicate, and mean \pm SEM of the total number of cells cultured in nine wells was calculated. The percentage of viable cells (shown in parentheses) was calculated by dividing the number of viable cells by the initial cell number $\left(2 \times 10^{5}\right)$. ${ }^{*} P$ values were derived using student's $t$ test. 


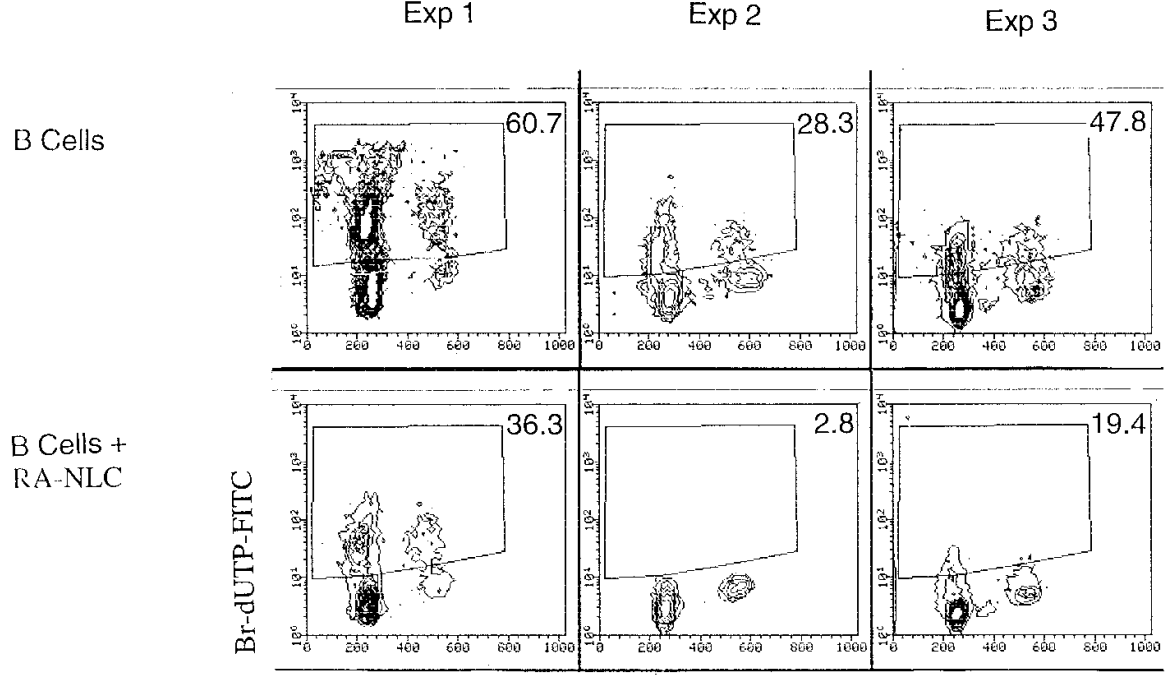

Propidium Iodide
Figure 5. RA-NLC protect B cells from spontaneous apoptosis. Peripheral B cells were cultured in medium alone or with RA-NLC77syn for $3 \mathrm{~d}$ and assessed for the percentage of apoptotic cells by the TUNEL technique. The numbers in each box indicate the percentage of apoptotic cells.

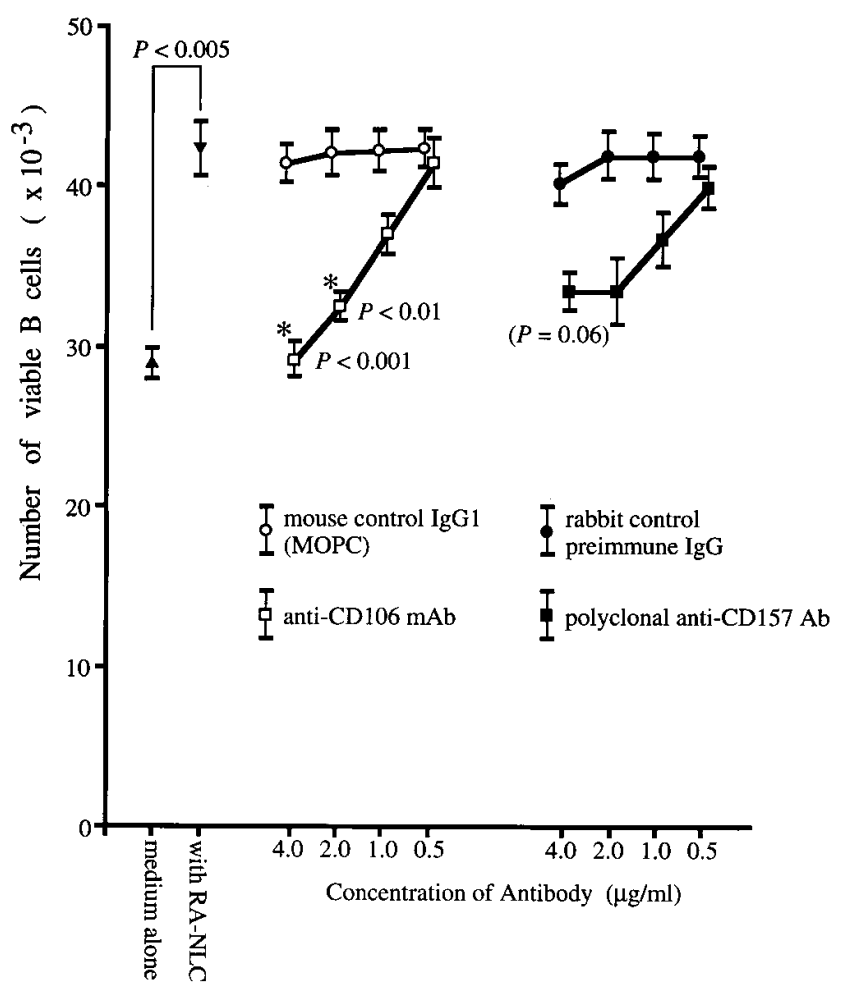

Figure 6. CD106 and CD157 are involved in the maintenance of B cell viability by RA-NLC. Peripheral B cells $\left(2 \times 10^{5}\right)$ were cultured in medium alone or with RA-NLC77syn and several concentrations of anti-CD106 mAb or anti-CD157 Ab or control Ab, and the number of viable B cells was counted at day 7 after staining with trypan blue. MOPC was used as the isotype-matched control $\mathrm{mAb}$ for antiCD106 mAb, P1.17 was used as the isotype-matched control $\mathrm{mAb}$ for anti-CD157 mAb (RF3), and preimmune rabbit IgG was used as the control for polyclonal antibody to CD157. The graph shows mean \pm SEM of the total number of cells cultured in nine wells. Significance between control Ab and anti-CD106 mAb or anti-CD157 Ab was derived using the student's $t$ test. motion of survival by synovial tissue-derived RA-NLC was also examined (Fig. 6). RA-NLC77syn promoted B cell survival that was significantly blocked by an mAb to CD106 in a concentration-dependent manner. At higher concentrations, anti-CD106 mAb completely blocked B cell survival promoted by RA-NLC77syn $(P<0.01)$ to the same level as B cells cultured in medium alone. Although anti-CD157 Ab appeared to block the survival of B cells partially, this effect was not statistically significant $(P=0.06)$. This may relate to the markedly diminished expression of CD157 by RA-NLC77syn (Fig. 3). Expression of a number of $\mathrm{B}$ cell surface antigens was increased by coculture with RA-NLC. These included CD38, CD95, CD23, CD69, and CD86 (data not shown). Of these, each was also increased by culture with control dermal fibroblasts (DT1 cells) except CD95, whose expression was increased on B cells by culture with RA-NLC, but not with DT1 cells (data not shown).

Secretion of Ig from peripheral B cells. Coculture with RANLC markedly increased secretion of Ig by peripheral blood $\mathrm{B}$ cells in the absence of stimulation by a polyclonal activator (Fig. 7). In contrast, a variety of control cells, including L cells, NIH3T3 cells, and DT1 exerted a considerably more modest impact on Ig production by B cells. In addition, RA-NLC enhanced IgG and IgA production by B cells stimulated with anti-CD3-activated $\mathrm{T}$ cells (data not shown). The effect of RA-NLC was significantly greater than that of human fibroblasts (DT1). The impact of RA-NLC on proliferation of peripheral blood B cells and a variety of B cell lines was examined. Despite the positive influence on $\mathrm{Ig}$ production previously noted, RA-NLC had no effect on initial proliferation of either peripheral blood B cells or a variety of B cell lines (data not shown).

Support of the outgrowth of B cell lines by RA-NLC. Despite the lack of an impact on initial cellular proliferation, clusters of growing cells were observed after a 7-wk incubation of B cells with RA-NLC, but not with DT1 cells (Fig. 8). By limiting dilution analysis, the precursor frequency of peripheral $\mathrm{B}$ cells generating outgrowth was $\sim 1$ in 12,500 (Fig. 9). Each of 


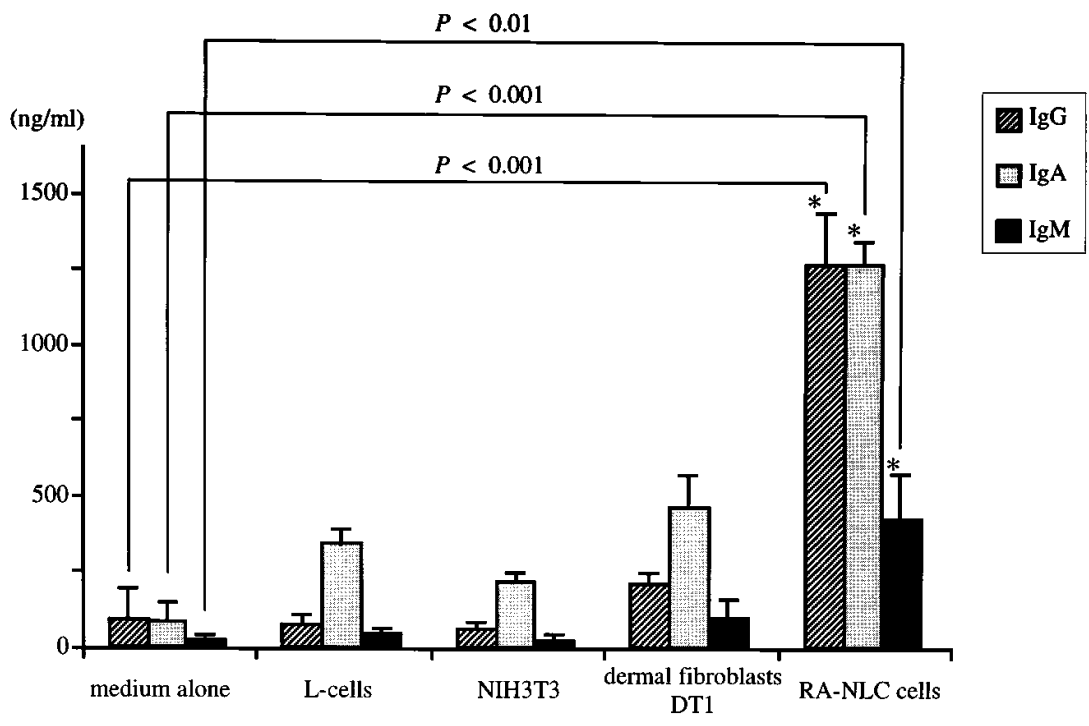

Figure 7. RA-NLC induce secretion of immunoglobulin from peripheral B cells. Peripheral B cells $\left(5 \times 10^{4}\right)$ were cultured in medium alone or with mouse fibroblasts (L-cells, NIH3T3 cells), human dermal fibroblasts (DT1), or with RANLC33BM with no other stimulation. The supernatants were harvested after $12 \mathrm{~d}$ of culture and Ig content was analyzed by isotype-specific ELISA. Data from three experiments are shown and expressed as mean \pm SEM. $P$ values were derived using the student's $t$ test. the B cell lines produced by culture of peripheral B cells with RA-NLC expressed EBV-encoded mRNA (data not shown). As noted previously, however, RA-NLC did not express EBVencoded gene products.

\section{Discussion}

Rheumatoid synovitis is characterized by the local activation of $B$ cells and the production of large amounts of $\operatorname{Ig}(36,37)$. It has been suggested that synoviocytes may contribute to the stimulation of B cell differentiation within the synovium (12, 13). Recently, cells with nurse cell characteristics have also been found in rheumatoid synovium and bone marrow $(10,11$; Takeuchi, E., T. Tomita, T. Toyosaki-Maeda, H. Hashimoto, M. Kaneko, H. Takano, K. Sugamoto, R. Suzuki, and T. Ochi, manuscript submitted for publication; Tomita, T., E. Takeuchi, T. Toyosaki-Maeda, H. Oku, M. Kaneko, H. Takano, K. Suga- moto, K. Ohzono, R. Suzuki, and T. Ochi, manuscript submitted for publication). To examine the possibility that NLC might contribute to systemic and local activation of $\mathrm{B}$ cells within the synovium, RA-NLC clones were established from both sites and their capacity to promote $\mathrm{B}$ cell responses analyzed. The RA-NLC clones were identified as nurse cells because they supported pseudoemperipolesis by a $\mathrm{T}$ cell lymphoma line, a characteristic that is considered to be specific for nurse cells and to distinguish them from other cell types, including fibroblasts (6-9). The RA-NLC clones also supported pseudoemperipolesis of B lymphoma cells as was recently reported for human skin-derived nurse cell clones (9) as well as bone marrow and synovial derived NLC (Takeuchi, E., T. Tomita, T. Toyosaki-Maeda, H. Hashimoto, M. Kaneko, H. Takano, R. Sugamoto, R. Suzuki, and T. Ochi, manuscript submitted for publication; Tomita, T., E. Takeuchi, T. ToyasakiMaeda, H. Oku, M. Kaneko, H. Takano, K. Sugamoto, K.

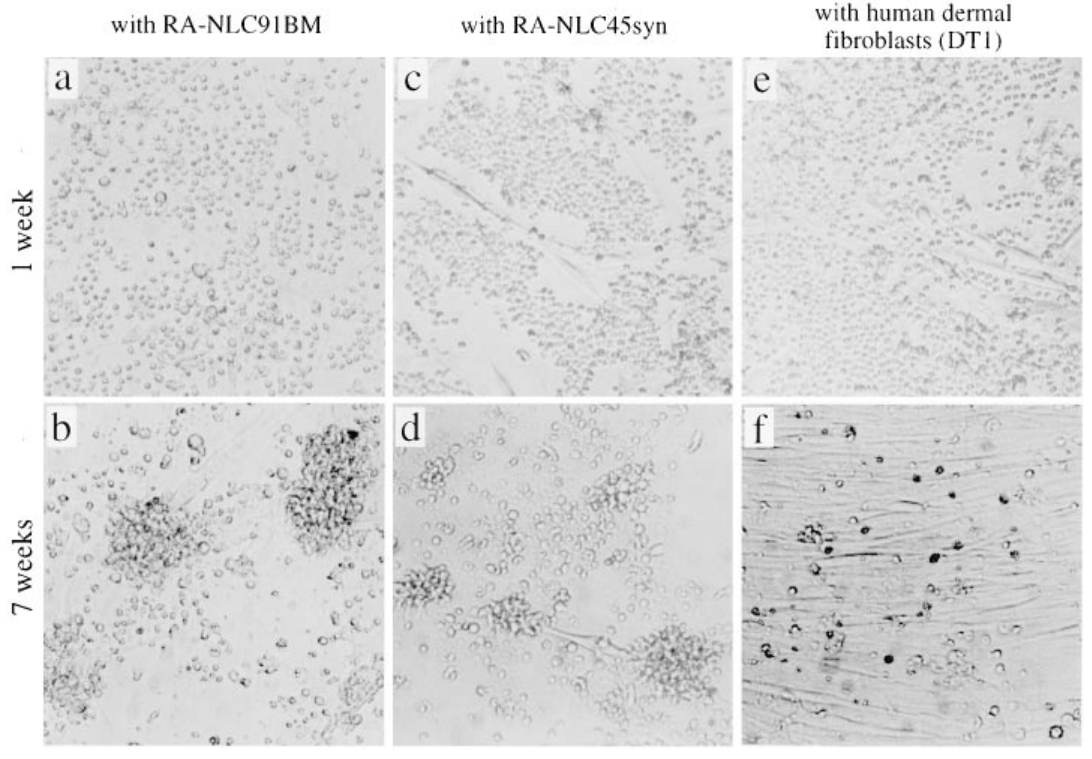

Figure 8. Outgrowth of B cells with RA-NLC. Long-term culture of normal peripheral B cells with RA-NLC $(a-d)$ or human dermal fibroblasts $(e$ and $f$ ) was performed. B cells were observed by phase-contrast microscopy after a culture of $1(a$, $c$, and $e$ ) and $7 \mathrm{wk}(b, d$, and $f)$, respectively. At 1 wk, approximately one-third of B cells were alive in all conditions $(a, d$, and $g)$. After 7 wk of culture with RA-NLC, B cell aggregations and blast cells were observed, whereas all of the B cells were dead in culture with DT1. $\times 60$. 


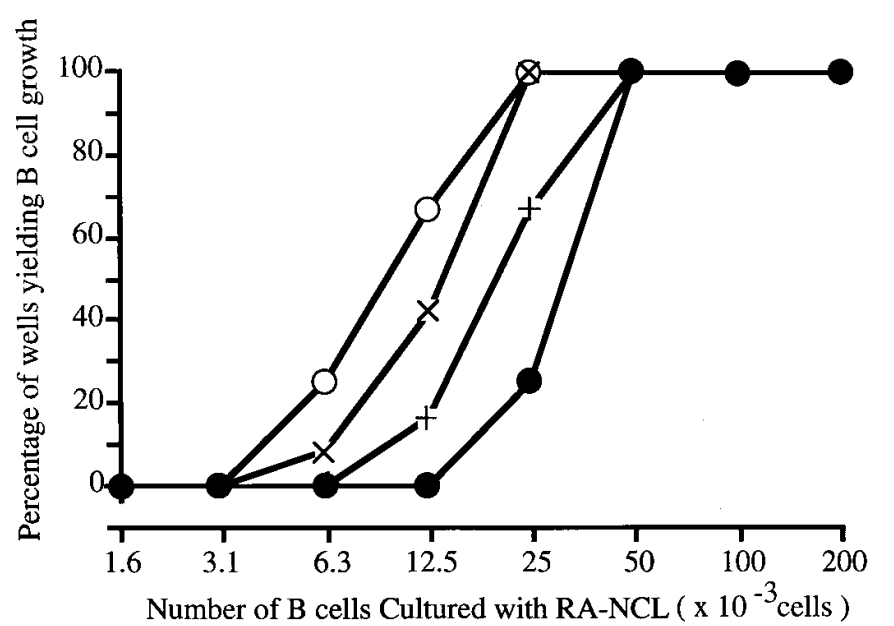

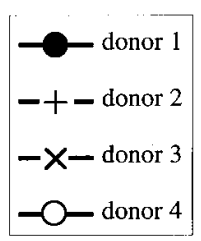

Figure 9. RA-NLC promote outgrowth of a small population of B cells. Several densities of peripheral B cells from four different donors were cultured with RA-NLC91BM for 4 wk in 96-well flatbottomed plates. The vertical axis shows percentage of wells yielding B cell growth, and horizontal axis shows number of B cells initially cultured in each well.
Ohzono, R. Suzuki, and T. Ochi, manuscript submitted for publication). Although peripheral B cells bound to RA-NLC, they did not migrate beneath them. However, RA-NLC induced a number of B cell functional activities, presumably as a result of signals transmitted during physical interactions between the cell types.

Nurse cells are thought to be of mesenchymal origin and are considered to represent a unique cell lineage. Despite extensive characterization, however, including analysis of surface phenotype and cytokine production, the most unique characteristic of these cells remains their capacity to support pseudoemperipolesis by thymocytes and some lymphoma cells in vitro (6-9). The nurse cell clones derived from RA bone marrow and synovium share characteristics with nurse cells derived from other sites (6-9), including their morphologic appearance as large, adherent cells with an irregular shape and multiple dendritic processes. As with other nurse cell populations, their appearance was distinctly different from that of monocyte/macrophages or of fibroblasts. Moreover, the RANLC were CD68 negative (data not shown) and proliferated in culture, making it very unlikely that they were members of the myeloid lineage. Furthermore, they constitutively expressed CD106 (VCAM-1) after long-term culture in the absence of cytokine stimulation. Although synovial fibroblasts express CD106 in situ $(12,38,39)$, in vitro culture in the absence of cytokines results in the loss of expression of this adhesion molecule $(12,40,41)$. Thus, constitutive expression of CD106 (VCAM-1) appears to be a characteristic of nurse cell lines, permitting them to be distinguished from fibroblasts. Of note, constitutive expression of CD106 by RA-NLC appears to be greater than that seen in human skin-derived nurse cells (9), although each of these populations is clearly positive. Moreover, constitutive expression of CD106 appears to be of importance in nurse cell function, as it has been shown to play a central role in pseudoemperipolesis (7). In summary, NLC can be derived from RA synovium and bone marrow and they appear to play an important role in promoting $\mathrm{B}$ cell viability by blocking spontaneous apoptosis and also facilitating differentiation of B cells into antibody-secreting cells.

Of note, RA-NLC also expressed CD157 or BST-1, a glycosyl-phosphatidylinositol (GPI)-anchored protein, which has been reported to facilitate the growth of murine pre-B cell lines in vitro (16-23, 33-35). CD157 is known to be expressed by bone marrow stromal cell lines, $\mathrm{T}$ and $\mathrm{B}$ lymphocyte progenitor cells, mature myeloid cells, and the reticular cells in splenic white pulp, lymph nodes, and Peyer's patches; it is also known to be expressed in the gut $(16,42-46)$. Although CD157 expressed by bone marrow stromal cells can promote the growth of a pre-B cell line in vitro (16), engagement of CD157 itself also costimulated proliferation of anti-CD3-activated pre-T cells, promoted the generation of $\alpha \beta$ T cell receptor expressing $\mathrm{T}$ cells in fetal thymic organ culture (45), and also induced tyrosine phosphorylation in myeloid cells (47). Thus, CD157 may function both as a signaling molecule on RA-NLC and as a receptor for an as yet unidentified ligand that provides activation signals to pre-B cells and perhaps other cell types. The wide distribution of BST-1 in the reticular cells in spleen and lymph node (44) suggests that it might have a broader range of functional activities.

RA-NLC produced a variety of cytokines that could contribute to inflammation and propagate immune responses. In general, the array of cytokines produced by RA-NLC was similar to that produced by skin-derived nurse cells (9). One major difference between synovial- and bone marrow-derived RA-NLC related to the production of IL-7 that was secreted by bone marrow-derived, but not synovial RA-NLC. This could be an important difference because IL-7 is a stromal cell-derived factor that stimulates B-lineage cell growth and maturation (48). Additional RA-NLC clones will need to be screened to confirm this difference, however, as only some skin-derived nurse cell lines, but no skin-derived nurse cell clones produced IL-7 (9).

RA-NLC promoted survival of peripheral blood B cells by blocking spontaneous apoptosis. The activity of RA-NLC was much greater than the nonspecific effect of human or mouse fibroblasts and could not be explained by the activity of secreted factors. Previous reports have shown that synoviocytes could promote the survival of T cells (49) and B cells (13). An adhesion molecule-mediated mechanism has been suggested to account for T cell survival (49), but the mechanism by which synoviocytes promote $\mathrm{T}$ cell survival has not been further delineated. Moreover, the possible contamination of the synoviocytes used in these studies with nurse-like cells has not been evaluated. In these studies, RA-NLC were found to be 
more effective than fibroblasts in maintaining B cell viability by blocking spontaneous apoptosis. Moreover, the mechanism involved the activity of two surface molecules constitutively expressed by RA-NLC, CD106, and CD157. As mentioned above, CD157 expressing bone marrow stromal cells previously have been shown to enhance proliferation of a pre-B cell line (16), but this is the first indication that CD157 may have a functional impact on mature peripheral B cells. Although recombinant soluble CD157 alone had no effect on spontaneous B cell apoptosis, together with RA-NLC, enhanced protection from apoptosis was noted. This finding, along with the data from blocking studies with antibodies to CD157, strongly implied that RA-NLC protected B cells from apoptosis by delivering two signals to B cells, one of which may be provided by CD157 engaging an unknown ligand on the B cell.

The second signal that protected B cells from apoptosis was provided by CD106, a molecule that was also constitutively expressed by RA-NLC and could be further upregulated by IFN- $\gamma$. An interaction between CD106 expressed by the RA-NLC and its ligand, CD49d/CD29 $\left(\alpha_{4} \beta_{1}\right.$, VLA- 4$)$ expressed by the B cell, appeared to be essential for maintenance of $B$ cell viability and prevention of apoptosis. Previous evidence has shown that CD106 is essential for other functions of nurse cells such as the induction of pseudoemperipolesis (7). Moreover, CD49d/CD29 engagement has recently been shown to provide a costimulatory signal to human B cells (50). Thus, interactions between RA-NLC-expressed CD106 and B cell-expressed CD49d/CD29 are reasonable candidates to provide viability promoting signals to B cells.

Although RA-NLC failed to support initial B cell proliferation, they supported increased Ig production by otherwise unstimulated peripheral B cells or B cells activated with antiCD3-stimulated T cells. Of note, RA-NLC were much more effective than fibroblasts at stimulating resting $\mathrm{B}$ cells to produce Ig. Although the mechanism of this phenomenon is unclear, it does not appear to be related to the CD40 signaling pathway as the RA-NLC failed to express CD40 ligand (CD154), even after stimulation with IFN $\gamma$. It is possible that the molecules involved in the induction of Ig production are the same as those promoting viability, namely either CD157, CD106, or both. The possibility that these molecules provide signals to mature B cells that facilitate Ig production is consistent with the expression of CD157 by reticular cells in spleen and lymph node (44) and the recently described role of signaling via CD49d/CD29 in facilitating Ig production by peripheral $\mathrm{B}$ cells (50). This possibility is currently being examined. Regardless of the mechanism, the data are consistent with the conclusion that NLC in the rheumatoid synovium and bone marrow play a role in the local and systemic overreactivity of $B$ cells characteristic of RA.

RA-NLC also supported the outgrowth of EBV-transformed B lymphoblastoid cells from normal B cells. Of importance, the RA-NLC were not infected with EBV, as has been reported for some synovial membrane-derived fibroblasts (51). Moreover, RA-NLC did not facilitate growth of EBVtransformed B lymphoblastoid cell lines, suggesting that they facilitated outgrowth of latently transformed B cells from peripheral blood. The precursor frequency of B cells undergoing long-term growth when cultured on RL-NLC $(1: 12,500)$ was comparable to the frequency of B cells latently infected with EBV in adult peripheral blood $(52,53)$ supporting this conclusion. The mechanism whereby RA-NLC promote the out- growth of EBV-transformed B lymphoblastoid cell lines from human peripheral B cells is unknown, but is likely to involve more than nonspecific support of viability, as human fibroblasts supported B cell viability somewhat, but failed to facilitate the outgrowth of EBV-transformed B lymphoblastoid cell lines. Whether similar surface molecules are involved in this process as were involved in the maintenance of B cell viability is currently unknown, but is the subject of ongoing investigation.

In rheumatoid synovium, germinal center-like structures containing B cells aggregated around cells resembling follicular dendritic cells (FDC) develop (12). The exact lineage of these FDC-like cells is unclear, but they and FDC in secondary lymphoid organs have certain characteristics in common with RA-NLC. For example, synovial FDC-like cells express CD106 at high levels $(12,54)$. Constitutive expression of CD106 appears to be a feature of both NLC and FDC. In this regard, some (55) but not all (56) FDC lines derived from human tonsil express high levels of CD106. Importantly, CD106 plays a critical role in the interaction of FDC with B cells both in vivo and in vitro $(55,57,58)$. Moreover, at least one FDClike line has been shown to express CD157 (55). In addition, FDC-like lines are similar to nurse cell lines in vitro, in that both can promote pseudoemperipolesis (59). Finally, both FDC and nurse cells can promote B cell viability. Thus, an FDC-like line promoted the viability of tonsillar B cells (56), whereas freshly prepared FDC promoted the viability of germinal center tonsillar B cells in a CD49d/CD29-dependent manner (60). There are, however, differences between FDC lines and RA-NLC, including the cytokines produced (61) and whether they interact uniquely with B cells $(58,61)$ or with both T and B cells (59), as is typical of nurse cells. In addition, FDC lines appear to support emperiopolesis $(56,59,60)$ as well as the pseudoemperipolesis (59) typical of nurse cells (6-9). Despite these discrepancies, the results suggest the possibility that RA-NLC and FDC-like cells at inflammatory sites or even in secondary lymphoid organs have many overlapping functional and phenotypic features. However, RA-NLC fail to express CD21 or CD35, characteristic markers of classic FDC (62-64). The absence of these markers on RA-NLC may be related to the observation that although CD21 and CD35 are expressed by FDC in situ, they are rapidly lost when these cells are cultured in vitro $(55,56,59,61)$. Of note, these markers can be induced on synoviocytes by stimulation with the proinflammatory cytokines TNF- $\alpha$ and IFN $\gamma$ (12). In this study, IFN $\gamma$ upregulated expression of both CD106 and CD157 by RANLC. If this cytokine, in conjunction with TNF- $\alpha$ also upregulated expression of CD21 and CD35 by RA-NLC, the cells would then exhibit the phenotype of synovial FDC. In conjunction with the capacity of RA-NLC to facilitate B cell functional activity, cytokine-activated RA-NLC may well account for the aggregates of B cells and CD106 expressing FDC-like cells (54) and the local activation of B cells and immunoglobulin production characteristic of rheumatoid synovitis $(36,37)$.

\section{Acknowledgments}

The authors are grateful to Dr. Amrie C. Grammer for her careful review of the manuscript.

This research was supported by National Institutes of Health Specialized Center of Research grant AR-39169 and by the program for Promotion of Fundamental Studies in Health Science of the Organi- 
zation for Drug ADR Relief, Research and Development Promotion and Product Review of Japan.

\section{References}

1. Wekerle, H., and U.P. Ketelsen. 1980. Thymic nurse cells-Ia-bearing epithelium involved in T-lymphocyte differentiation? Nature. 283:402-404.

2. Wekerle, H., U.P. Ketelsen, and M. Ernst. 1980. Thymic nurse cells. Lymphoepithelial cell complexes in murine thymuses: morphological and serological characterization. J. Exp. Med. 151:925-944.

3. Pezzano, M., Y. Li, D. Philp, C. Omene, M. Cantey, G. Saunders, and J.C. Guyden. 1995. Thymic nurse cell rescue of early CD4+CD8+ thymocytes from apoptosis. Cell. Mol. Biol. 41:1099-1111.

4. Pezzano, M., D. Philp, S. Stephenson, Y. Li, V. Reid, R. Maitta, and J.C. Guyden. 1996. Positive selection by thymic nurse cells requires IL-1 beta and is associated with an increased Bcl-2 expression. Cell. Immunol. 169:174-184.

5. Iwabuchi, K., K. Nakayama, R.L. McCoy, F. Wang, T. Nishimura, S. Habu, K.M. Murphy, and D.Y. Loh. 1992. Cellular and peptide requirements for in vitro clonal deletion of immature thymocytes. Proc. Natl. Acad. Sci. USA. 89:9000-9004.

6. Itoh, T., H. Doi, S. Chin, T. Nishimura, and S. Kasahara. 1988. Establishment of mouse thymic nurse cell clones from a spontaneous BALB/c thymic tumor. Eur. J. Immunol. 18:821-824.

7. Miyake, K., Y. Hasunuma, H. Yagita, and M. Kimoto. 1992. Requirement for VLA-4 and VLA-5 integrins in lymphoma cells binding to and migration beneath stromal cells in culture. J. Cell Biol. 119:653-662.

8. Hiai, H., Y. Nishi, T. Miyazawa, Y. Matsudaira, and Y. Nishizuka. 1981. Mouse lymphoid leukemias: symbiotic complexes of neoplastic lymphocytes and their microenvironments. J. Natl. Cancer Inst. 66:713-722.

9. Iwagami, S., S. Furue, T. Toyosaki, T. Horikawa, H. Doi, S. Satomi, T. Itoh, T. Sakata, and R. Suzuki. 1994. Establishment and characterization of nurse cell-like clones from human skin. Nurse cell-like clones can stimulate autologous mixed lymphocyte reaction. J. Immunol. 153:2927-2938.

10. Tomita, T., T. Toyosaki, S. Kawamura, H. Oku, R. Suzuki, H. Hashimoto, K. Hayashida, J. Hashimoto, and T. Ochi. 1996. Stromal cells established from bone marrow of RA patients could induce and maintain unusual myeloid cells $\left(\mathrm{CD} 14^{+} \mathrm{CD} 15^{+}\right.$cells) specific to severe RA patients. Arthritis Rheum. Suppl. 39:194.

11. Toyosaki, T., Y. Tsuruta, T. Yoshioka, T. Tomita, R. Suzuki, and T. Ochi. 1996. Recognition of synovial cell antigen by $\mathrm{CD}^{+} \mathrm{CD}^{-} \mathrm{T}$ cell clones established from rheumatoid arthritis patients. Arthritis Rheum. Suppl. 39:266.

12. Edwards, J.C.W., R.D. Leigh, and G. Cambridge. 1997. Expression of molecules involved in B lymphocyte survival and differentiation by synovial fibroblasts. Clin. Exp. Immunol. 108:407-414.

13. Dechanet, J., P. Merville, I. Durand, J. Banchereau, and P. Miossec. 1995. The ability of synoviocytes to support terminal differentiation of activated B cells may explain plasma cell accumulation in rheumatoid synovium. $J$. Clin. Invest. 95:456-463.

14. Arnett, F.C., S.M. Edworthy, D.A. Bloch, D.J. McShane, J.F. Fries, N.S. Cooper, L.A. Healey, S.R. Kaplan, M.H. Liang, H.S. Luthra, et al. 1988. The American Rheumatism Association 1987 revised criteria for the classification of rheumatoid arthritis. Arthritis Rheum. 31:315-324.

15. Wysocki, L.J., and V.L. Sato. 1978. "Panning" for lymphocytes: a method for cell selection. Proc. Natl. Acad. Sci. USA. 75:2844-2848.

16. Kaisho, T., J. Ishikawa, K. Oritani, J. Inazawa, H. Tomizawa, O. Muraoka, T. Ochi, and T. Hirano. 1994. BST-1, a surface molecule of bone marrow stromal cell lines that facilitates pre-B-cell growth. Proc. Natl. Acad. Sci. USA. 91:5325-5329.

17. Okuyama, Y., K. Ishihara, N. Kimura, Y. Hirata, K. Sato, M. Itoh, and L.B. Ok. 1996. Human BST-1 expressed on myeloid cells functions as a receptor molecule. Biochem. Biophys. Res. Commun. 228:838-845.

18. Ishikawa, J., T. Kaisho, H. Tomizawa, B.O. Lee, Y. Kobune, J. Inazawa, M. Itoh, T. Ochi, K. Ishihara, et al. 1995. Molecular cloning and chromosomal mapping of a bone marrow stromal cell surface gene, BST2, that may be involved in pre-B-cell growth. Genomics. 26:527-534.

19. Lee, B.O., K. Ishihara, K. Denno, Y. Kobune, M. Itoh, O. Muraoka, T. Kaisho, T. Ochi, and T. Hirano. 1996. Elevated levels of the soluble form of bone marrow stromal cell antigen 1 in the sera of patients with severe rheumatoid arthritis. Arthritis Rheum. 39:629-637.

20. Dong, C., D. Willerford, F.W. Alt, and M.D. Cooper. 1996. Genomic organization and chromosomal localization of the mouse $\mathrm{Bp} 3$ gene, a member of the CD38-ADP-ribosyl cyclase family. Immunogen. 45:35-43.

21. Muraoka, O., H. Tanaka, M. Itoh, K. Ishihara, and T. Hirano. 1996. Genomic structure of human BST-1. Immunol. Lett. 54:1-4.

22. Ferrero, E., and F. Malavasi. 1997. Human CD38, a leukocyte receptor and ectoenzyme, is a member of a novel eukaryotic gene family of nicotinamide adenine dinucleotide ${ }^{+}$-converting enzymes: extensive structural homology with the genes for murine bone marrow stromal cells antigen 1 and aplysian ADPribosyl cyclase. J. Immunol. 159:3858-3865.

23. Hirata, Y., N. Kimura, K. Sato, Y. Ohsugi, S. Takasawa, H. Okamoto, T.
Kaisho, K. Ishihara, and T. Hirano. 1994. ADP ribosyl cyclase activity of a novel bone marrow stromal cell surface molecule, BST-1. FEBS (Fed. Eur. Biochem. Soc.) Lett. 356:244-248.

24. de Galdiero, M.E., and A. Marcatili. 1997. Cytokine and adhesion molecule expression in human monocytes and endothelial cells stimulated with bacterial heat shock proteins. Infect. Immun. 65:699-707.

25. Nakajima-Iijima, S., H. Hamada, P. Reddy, and T. Kakunaga. 1985. Molecular structure of the human cytoplasmic beta-actin gene: interspecies homology of sequences in the introns. Proc. Natl. Acad. Sci. USA. 82:6133-6137.

26. Cocks, B.G., R. de Waal Malefyt, J.P. Galizzi, J.E. de Vries, and G. Aversa. 1993. IL-13 induces proliferation and differentiation of human B cells activated by the CD40 ligand. Int. Immunol. 5:657-663.

27. Newkirk, M.M., K.N. Watanabe Duffy, J. Leclerc, N. Lambert, and J.B. Shiroky. 1994. Detection of cytomegalovirus, Epstein-Barr virus and herpes virus-6 in patients with rheumatoid arthritis with or without Sjögren's syndrome. Br. J. Rheumatol. 33:317-322.

28. Knecht, H., R. Sahli, P. Shaw, C. Meyer, E. Bachmann, B.F. Odermatt, and F. Bachmann. 1990. Detection of Epstein-Barr virus DNA by polymerase chain reaction in lymph node biopsies from patients with angioimmunoblastic lymphadenopathy. Br. J. Haematol. 75:610-614.

29. Jumper, M.D., J.B. Splawski, P.E. Lipsky, and K. Meek. 1994. Ligation of CD40 induces sterile transcripts of multiple Ig $\mathrm{H}$ chain isotypes in human B cells. J. Immunol. 152:438-445.

30. Gorczyca, W., J. Gong, and Z. Darzynkiewicz. 1993. Detection of DNA strand breaks in individual apoptotic cells by the in situ terminal deoxynucleotidyl transferase and nick translation assays. Cancer Res. 53:1945-1951.

31. Tohma, S., and P.E. Lipsky. 1991. Analysis of the mechanisms of T celldependent polyclonal activation of human B cells. Induction of human B cell responses by fixed activated T cells. J. Immunol. 146:2544-2552.

32. Mosmann, T. 1983. Rapid colorimetric assay for cellular growth and survival: application to proliferation and cytotoxicity assays. J. Immunol. Methods. 65:55-63.

33. Itoh, M., K. Ishihara, H. Tomizawa, H. Tanaka, Y. Kobune, J. Ishikawa, and T. Hirano. 1994. Molecular cloning of murine BST-1 having homology with CD38 and Aplysia ADP-ribosyl cyclase. Biochem. Biophys. Res. Commun. 203: 1309-1317.

34. Kajimoti, Y., J. Miyagawa, K. Ishihara, Y. Okuyama, Y. Fujitani, M. Itoh, T. Kaisho, T. Matsuoka, H. Watada, T. Hanafusa, Y. Yamasaki, Y. Matsuzawa, and T. Hirano. 1996. Pancreatic islet cells express BST-1, a CD38-like surface molecule having ADP-ribosyl cyclase activity. Biochem. Biophys. Res. Commun. 219:941-946.

35. Prasad, G.S., D.E. McRee, E.A. Stura, D.G. Levitt, H.C. Lee, and C.D. Stout. 1996. Crystal structure of Aplysia ADP ribosyl cyclase, a homologue of the bifunctional ectozyme CD38. Nature Struct. Biol. 3:957-964.

36. Smiley, J.D., C. Sachs, and M. Ziff. 1968. In vitro synthesis of immunoglobulin by rheumatoid synovial membrane. J. Clin. Invest. 47:624-632.

37. Wernick, R., P.E. Lipsky, E. Marban-Arcos, J.J. Maliakkal, D. Edelbaum, and M. Ziff. 1985. IgG and IgM rheumatoid factor synthesis in rheumatoid synovial membrane cell cultures. Arthritis Rheum. 28:742-752.

38. Kriegsmann, J., G.M. Keyszer, T. Geiler, R. Brauer, R.E. Gay, and S. Gay. 1995. Expression of vascular cell adhesion molecule-1 mRNA and protein in rheumatoid synovium demonstrated by in situ hybridization and immunohistochemistry. Lab. Invest. 72:209-214.

39. Veale, D.J., and C. Maple. 1996. Cell adhesion molecules in rheumatoid arthritis. Drugs Aging. 9:87-92.

40. Marlor, C.W., D.L. Webb, M.P. Bombora, J.M. Greve, and M.L. Blue. 1992. Expression of vascular cell adhesion molecule I in fibroblast-like synoviocytes after stimulation with tumor necrosis factor. Am. J. Pathol. 140:10551060 .

41. Morales Ducret, J., E. Wayner, M.J. Elices, G. Firestein, and N. Zvaifler. 1992. $\alpha 4 / \beta 1$ Integrin (VLA-4) ligands in arthritis: vascular cell adhesion molecule expression in synovium and on fibroblast-like synoviocytes. Arthritis Rheum. 49:1424-1431.

42. Ishihara, K., Y. Kobune, Y. Okuyama, M. Itoh, B.O. Lee, O. Muraoka, and T. Hirano. 1996. Stage-specific expression of mouse BST-1/BP-3 on the early $\mathrm{B}$ and $\mathrm{T}$ cell progenitors prior to gene rearrangement of antigen receptor. Int. Immunol. 8:1395-1404.

43. McNagny, K.M., P.A. Cazenave, and M.D. Cooper. 1988. BP-3 alloantigen. A cell surface glycoprotein that marks early B lineage cells and mature myeloid lineage cells in mice. J. Immunol. 141:2551-2556.

44. McNagny, K.M., R.P. Bucy, and M.D. Cooper. 1991. Reticular cells in peripheral lymphoid tissues express the phosphatidylinositol-lined BP3 antigen. Eur. J. Immunol. 21:509-515.

45. Vicari, A.P., A.G. Bean, and A. Zlotnik. 1996. A role for BP-3/BST-1 antigen in early T cell development. Int. Immunol. 8:183-191.

46. Dong, C., J. Wang, P. Neame, and M.D. Cooper. 1994. The murine BP-3 gene encodes a relative of the CD38/NAD glycohydrolase family. Int. Immunol. 6:1353-1360.

47. Okuyama, Y., K. Ishihara, N. Kimura, Y. Hirata, K. Sato, M. Itoh, L.B. Ok, and T. Hirano. 1996. Human BST-1 expressed on myeloid cells functions as a receptor molecule. Biochem. Biophys. Res. Commun. 228:838-845.

48. Namen, A.E., S. Lupton, K. Hjerrild, J. Wignall, D.Y. Mochizuki, A. 
Schmierer, B. Mosley, C.J. March, D. Urdal, and S. Gillis. 1988. Stimulation of B-cell progenitors by cloned murine interleukin-7. Nature. 333:571-573.

49. Salman, M., D. Scheel-Toellner, A.P. Huissoon, D. Pilling, N. Shansadeen, H. Hyde, A.D. D'Angeac, P.A. Bacon, P. Emery, and A.N. Akbar. 1997. Inhibition of T cell apoptosis in the rheumatoid synovium. J. Clin. Invest. 99:439-446.

50. Silvy, A., P. Altevogt, P. Mondiere, C. Bella, and T. Defrance. 1997. A role for the VLA-4 integrin in the activation of human memory B cells. Eur. J. Immunol. 27:2757-2764.

51. Koide, J., K. Takada, M. Sugiura, H. Sekine, T. Ito, K. Saito, S. Mori, T. Takeuchi, S. Uchida, and T. Abe. 1997. Spontaneous establishment of an Epstein-Barr virus-infected fibroblast line from the synovial tissue of a rheumatoid arthritis patient. J. Virol. 71:2478-2481.

52. Klein, G. 1994. Epstein-Barr virus strategy in normal and neoplastic B cells. Cell. 71:791-793.

53. Kieff, E. 1996. Epstein-Barr virus and its replication. In Virology. B.N. Fields, D.N. Knipe, P.M. Howley, R.M. Chanock, T.P. Monath, J.L. Melnick, B. Roizman, and S.E. Straus, editors. Lippicott-Raven, Philadelphia. 2343-2396.

54. Edwards, J.C., L.S. Wilkinson, P. Speight, and D.A. Isenberg. 1993. Vascular cell adhesion molecule 1 and alpha 4 and beta 1 integrins in lymphocyte aggregates in Sjögren's syndrome and rheumatoid arthritis. Ann. Rheum. Dis. 52:806-811.

55. Clark, E.A., K.H. Grabstein, A.M. Gown, M. Skelly, T. Kaisho, T. Hirano, and G.L. Shu. 1995. Activation of B lymphocyte maturation by a human follicular dendritic cell line, FDC-1. J. Immunol. 155:545-555.

56. Lindhout, E., A. Lakeman, M.L.C.M. Mervissen, and C. de Groot. 1994. Functionally active Epstein Barr Virus transformed follicular dendritic cell-like lines. J. Exp. Med. 179:1173-1184.

57. Freedman, A.S., J.M. Munro, G.E. Rice, M.P. Bevilacqua, C. Morimoto, B.W. McIntyre, K. Rhynhart, J.S. Pober, and L.M. Nadler. 1990. Adhesion of human B cells to germinal centers in vitro involves VLA-4 and INCAM-110. Science. 249:1031-1033.

58. Koopman, G., H.K Parmentier, H.J. Schuurman, W. Newman, C J L.M. Meijer, and S.T. Pals. 1991. Adhesion of human B cells to follicular dendritic cells involves both the lymphocyte function associated antigen 1/intercellula adhesion molecule 1 and very late antigen 4/vascular adhesion molecule 1 pathways. J. Exp. Med. 173:1297-1304.

59. Tsunoda, R., M. Nakayama, E. Heinen, K. Miyake, K. Suzuki, N. Sugai, and M. Kojima. 1992. Emperipolesis of lymphoid cells by human follicular dendritic cells in vitro. Virchows Arch. B Cell Pathol. 62:69-78.

60. Lindhout E., M.L.C.M. Mervissen, J. Kwekkeboom, J.M. Tager, and C. deGroot. 1993. Direct evidence that human follicular dendritic cells rescue germinal center B cells from death by apoptosis. Clin. Exp. Immunol. 91:330-336.

61. Clark, E.A., K.H. Grabstein, and G.L. Shu. 1992. Cultured human follicular dendritic cells. Growth characteristics and interactions with B lymphocytes. J. Immunol. 148:3327-3335.

62. Bosseloir, A., E. Heinen, T. Defrance, F. Bouzhazha, N. Antoine, and L.J. Simar. 1994. Moabls MAS516 and 5B5, two fibroblast markers, recognize human follicular dendritic cells. Immunol. Lett. 42:49-54.

63. Pallesen, G., and O. Myhre-Jensen. 1987. Immunophenotypic analysis of neoplastic cells in follicular dendritic cell sarcoma. Leukemia. 7:549-557.

64. Humphrey, J.H., D. Grennan, and V. Sundaram. 1984. The origin of follicular dendritic cells in the mouse and the mechanism of trapping of immune complexes on them. Eur. J. Immunol. 14:859-864. 